Zsóka Gelle

\title{
Treasure Texts on the Age of Decline: Prophecies Concerning the Hidden Land of Yolmo, their Reception and Impact
}

The toponym "Yolmo" appears in Tibetan texts from the fifteenth century onwards and refers to an area near the border of Tibet with Nepal, corresponding to today's Nepalese districts of Sindupalchok and the edge of Rasuwa. Yolmo is described as one of the Hidden Lands (sbas yul) concealed by Padmasambhava in the eighth century and opened by sNgags 'chang Śākya bZangpo, a famous "treasure-revealer" (gter ston), at the beginning of the sixteenth. The first part of this article explores Buddhist cosmology and eschatology, teachings regarding the Age of Decline, and the way these ideas were transferred between cultures and reached Tibet. This discussion provides the wider context for the subsequent analysis of the prophecies attributed to Rig 'dzi rGod ldem, a late fourteenth/early fifteenth century Tibetan treasure-revealer. His prophecies about the End Times warn of foreign invasion and urge people to escape Tibet and find a Hidden Land in the Himalaya to save their lives and preserve Buddhist teachings. Five of these describe the Hidden Land of Yolmo and the way in which it could be transformed into an ideal place to serve as a safe haven for Buddhist practitioners. The third and final part highlights the activities of a Tibetan lama, gTer dbon Nyi ma seng ge, who followed these prophecies in the early eighteenth century and settled in Yolmo.

According to the rNying ma tradition of Tibetan Buddhism, the great Tantric master Padmasambhava and his consort Ye she mtsho rgyal concealed spiritual treasures (gter $\mathrm{ma}$ ) in the eighth ${ }^{1}$ century, to be revealed in the future, when conditions were right for their dissemination and practice. ${ }^{2}$ They were concealed in the form of texts, religious objects, remote valleys and lands, or as teachings buried in the mind stream of future reincarnations of Padmasambhava's direct disciples.

The valleys and lands concealed for future discovery are called sbas yul in Tibetan, "hidden lands", and considered to be places of refuge for Tibetans during foreign invasion or political unrest in an Age of Decline, when the preservation of the Buddhist teaching is in danger. The sbas yul is a geographical place, capable of supporting a sizeable population engaged in agro-pastoral work, a bountiful land where resources are plentiful and easily available. It is a place where an idealised

1 All datings refer to CE datings.

2 gTer ma or "treasure" became one of the three types of transmission of the rNying ma School, the other two being $b k a$ ' $m a$ (direct transmission from master to disciple in an unbroken line), and dag snang (pure vision).

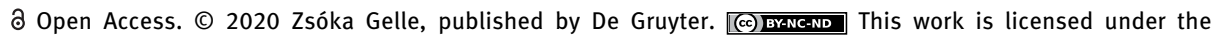
Creative Commons Attribution-NonCommercial-NoDerivatives 4.0 License.

https://doi.org/10.1515/10.1515/9783110597745-014 
version of Tibetan society can be sustained far from all the political trouble of Tibet. In a spiritual sense, it is seen as a multi-layered mandala, where practitioners can achieve higher realization. ${ }^{3}$ My research concentrates on one particular Hidden Land, sBas yul Yol mo gangs ra, ${ }^{4}$ the Hidden Land of Yolmo Snow Enclosure, a place identified geographically with a mountainous area in Nepal northeast of Kathmandu, close to the Tibetan border. There are several treasure texts available which describe this locality, how to get there, and how to transform the place into a sacred realm.

Before discussing these treasure texts and their impact, I would like to explore the underlying narrative of Buddhist cosmology, to demonstrate how certain elements emphasized in the treasure texts concerning Yolmo are deeply rooted in the early Buddhist scriptural tradition, and how they were transmitted between cultures, schools, and lineages.

\section{The Underlying Narrative}

The time of the historical Buddha, ${ }^{5}$ Buddha Sākyamuni, is often described as a kind of Golden Age in Buddhist literature. Over the centuries, various predictions and theories developed concerning the duration and decline of the Buddha's teaching, and its final disappearance from the human realm. ${ }^{6}$ Different timetables ascribe different numbers of years to the periods of decline, ranging from a minimum of five hundred years to more than ten thousand divided into five-hundred-year periods. The number of five-hundred-year periods that a text posits reflects the historical era

3 Some of the most important contributions by Western scholars exploring Tibetan sources on hidden lands are Reinhard, "Khembalung," 5-35; Bernbaum, The Way to Shambhala; Brauen-Dolma, "Milleniarism in Tibetan Religion," 245-256; Orofino, "Tibetan Myth of the Hidden Valley in the Visionary Geography of Nepal," 239-271; Diemberger, "Gangla Tshechu, Beyul Khembalung," 6072; Diemberger, "Beyul Khenbalung, the Hidden Valley of the Artemisia," 287-334; Ehrhard, "A 'Hidden Land' in the Nepalese-Tibetan Borderlands," 335-364; Ehrhard, "The Role of "Treasure-Discoverers' and their Writings in the Search for Himalayan Sacred Lands," 227-239; Sardar-Afkhami, "Account of Padma-bkod," 1-21; Sardar-Afkhami, "The Buddha's Secret Gardens;" Childs, "Refuge and Revitalization," 126-158; Huber, “A Pilgrimage to La-phyi," 233-286; Huber, The Cult of the Pure Crystal Mountain; Boord, "Pilgrims Guide to the Hidden Land of Sikkim Proclaimed as a Treasure by Rig 'dzin Rgod kyi ldem 'phru can," 31-53; Mullard, Opening the Hidden Land.

4 Tib. sBas yul Yol mo gangs ra.

5 Lamotte uses $486 \mathrm{BC}$ as a working hypothesis for the nirvāna of the Buddha. Assuming that he lived for eighty years, his lifetime falls into the second half of the sixth century BC. See Lamotte, History of Indian Buddhism from the Origins to the Śaka Era, 14.

6 Sadakata, Buddhist Cosmology, 106; Lamotte, History of Indian Buddhism from the Origins to the Śaka Era, 192. 
in which it was written. All texts emphasize that the decline is caused primarily by human agency. ${ }^{7}$

The suttas no. 154-156 of the Anguttaranikāya list five things that lead to the decline and disappearance of the Dharma. These are when the bhikkhus (monks) do not listen to the Dharma; do not learn the Dharma; do not keep the Dharma in mind; do not examine the meaning of the teaching; and by not understanding it, do not practice it properly. ${ }^{8}$ Buddhist texts often warn of the emergence of a desire for possession in monastic communities, ${ }^{9}$ which is seen as another cause of decline. There is a sense of crisis in these texts, and a number of innovative practices and doctrines are developed in response to it.

In the frame story of the Cakkavattisinhanādasutta ${ }^{10}$ ("The Lion's Roar of the Wheel-Turning One") ${ }^{11}$ the Buddha urges his monks to cultivate mindfulness, morality, and restraint; however, the main narrative of the text does not mention any monks or the historical Buddha but talks about the moral decline of society in general terms and elaborates on the workings of cause and effect that bring forth the End Times. The main narrative is possibly a more ancient story, ${ }^{12}$ which talks about a wheel-turning monarch who stops ruling according to the Dharma. Because of this, his people become poor:

[...] from the growth of poverty, the taking of what was not given increased, from the increase of the theft, the use of weapons increased, from the increased use of weapons, the taking of life increased - and from the increase of the taking of life, people's life-span decreased [...] from eighty thousand to forty thousand years. ${ }^{13}$

The text describes that as a result of numberless unvirtuous deeds, the lifespan of people shortens, and their physical body deteriorates. At the beginning of an intermediate eon (antarakalpa) humans live for eighty thousand years, but by the end, in the darkest times, the average lifespan will be only ten years. The final event will be a seven-day war, ${ }^{14}$ when swords appear in people's hands and they hunt and kill

7 For a detailed description of different timetables, see Nattier, Once Upon a Future Time, 27-64 and Lamotte, History of Indian Buddhism from the Origins to the Saka Era, 192-198.

8 Anguttaranikāya, 3.176-180 (5.154-156). See The Numerical Discourses of the Buddha, 766-770.

9 See Anguttaranikāya, 3.108-110 (5.80), 715. The sutta states that in the future there will be monks who long for fine robes, good almsfood, comfortable housing, and socialising, and that in order to get these things they will leave their solitary dwellings and move to big cities. It warns monks that they should avoid entertaining these kinds of desire.

10 It is the 26th sutta of the Dighanikāya, 3.58-79. Nattier, Once Upon a Future Time, 13-15 mentions this briefly in order to prove that cosmic evolution and devolution was assumed by Buddhists from early on. The English translation of the title is from Thus Have I Heard, 395.

11 Dìghanikāya, 3.58-79 (26).

12 See Gombrich, How Buddhism Began.

13 Dìghanikāya, 3.68 (26.14) 399-400.

14 The expression used is "sword-interval" or satthantarakappa that seems to mark a turning point between two antarakalpas. It is ususally interpreted as a seven-day war. See Dīghanikāya, 602, en. 798. 
each other. Only the people who manage to hide in thickets of tall grass, dense jungle, forested woodland, inaccessible mid-river islands, or mountain valleys, survive. After the final war, these people will emerge from their hiding places and decide to live virtuously. As they refrain from negative actions, their lifespan increases, and their physical bodies improve as well. When they live again for eighty thousand years, Jambudvipa ${ }^{15}$ will be prosperous; it will have eighty-four thousand cities headed by Ketumatī, ${ }^{16}$ the royal capital. At that time a fully enlightened buddha will appear named Metteyya (Skt. Maitreya). In the discourse, the Buddha's Dharma of truth, morality and virtue indicates the way to liberation, and it is the basis of order in society, which can be ensured only by the presence of a righteous king. Since there is no buddha present in the End Times, the king has to replace him and serve as the "sovereign regulator". ${ }^{17}$ When the king is not ruling according to the Dharma, society disintegrates, and the negative actions of living beings give rise to negative processes.

There are notable variants between the texts, but even these very early works share the idea that both external and internal events will show the arrival of the End Times. Some of the external signs are that foreign armies invade India, persecute the followers of the Buddha, destroy stūpas and burn holy texts. Most of the sources mention three foreign kings ${ }^{18}$ who will attack India from three different directions: south, north and west. ${ }^{19}$ The internal signs of the End Times are also numerous. The most severe is that monks do not observe their vows and there is only a single $a r h a t^{20}$ and a single Tripițaka master ${ }^{21}$ left in the world, but during a quarrel both of them are killed. Thus the Dharma disappears from the world, the sky and earth grow dark, the earth quakes, and a shower of meteors burns everything. Māra and his retinue feel great joy, and a loud voice will be heard in the air: "As from

15 Tib. 'dzam bu'i gling. According to Buddhist cosmology, the world-mountain Sumeru around which the sun and moon revolve arises in the centre and is surrounded by a vast ocean with four continents in the four directions. The southernmost is Jambudvipa, the only place where beings can get enlightened by being born as human beings.

16 Identified with today's Benares in India.

17 Apple, "Eschatology and World Order in Buddhist Formations," at 114. Tambiah, World Conqueror and World Renouncer, 52.

18 According to the Dunhuang text these three kings are of the ya ba na, ba lhi ka, sha ku na. They are identified by Nattier, Once Upon a Future Time, 243 as the kings of the Greeks, Parthians and Śaka. Lamotte translates them as Yavana, Pahlava and Śakas and argues that this refers to a historical event which occured during the last two centuries BC (Lamotte, History of Indian Buddhism from the Origins to the Śaka Era, 201).

19 Nattier, Once Upon a Future Time, 239-250.

20 "One who is worthy." Someone who freed himself from the bonds of desire and who will not be reborn.

21 A honorary title given to those who were well versed in the three divisions of the Buddha's teachings: the sūtra, the vinaya and the abhidharma. 
today the Saddharma of the Sākya, the great recluse has disappeared."22 This is how the Mahāvibhāṣās $\bar{a} s t r a$ describes it, ${ }^{23}$ a text which, according to Taiken Kimura, was written around 150 CE. ${ }^{24}$

The Candragarbhasūtra is a much later Mahāyāna sūtra which was translated first into Chinese ${ }^{25}$ and then into Tibetan. It is treated as a separate work by the Tibetan bKa' 'gyur in its mDo (Sūtra) section. ${ }^{26}$ Its narrative opens with the Bodhisattva Candragarbha asking the Buddha: "How will the True Dharma finally disappear, for what reason will it decline, and who will bring it to an end?"27 The Buddha then recounts the story of the three kings who will invade India, and of the Prince of Kausāambī who fights against their armies for twelve years and after his triumph becomes the king. Having killed many people in the war, he wants to purify himself of his sins, and for this reason invites all Buddhist monks to come to his kingdom. The Dharma disappears from other parts of India, and Kausāāmbī becomes its last bastion. Then the king invites an arhat and a Vinaya Master (master of monastic discipline) to his court, and when the masters quarrel, the Vinaya master's disciples become angry and, whilst trying to defend their preceptor, kill the arhat. Then, in revenge, the Vinaya master is killed, and after a fight in the sarigha, no one remains alive. On seeing the dead bodies, the King of Kausaāmbì becomes so unhappy that he goes blind. His ministers try to please the king by disguising five hundred men as Buddhist mendicants. However, when these fake monks are unable to answer his questions, the king realizes that the Buddha's teaching has disappeared from the world and dies of sorrow. Aside from a few details, the main narrative is very similar to the one found in the Mahāvibhāṣāśāstra.

According to the Mahāyāna view, our present age is a kalpa of renovation-duration called Bhadrakalpa ${ }^{28}$ or "Auspicious Era", when a thousand buddhas appear. During the kalpa of renovation-duration a buddha can appear only during the antarakalpa ${ }^{29}$ of decrease, and not during the time of increase, when human beings live longer and are too content with life to listen to the teaching of the buddhas, or in the final period of decline when the human lifespan is between one hundred and ten years, and humans are too inferior to be able to respond to the teachings. ${ }^{30}$ Mahāyāna sūtra, just like other Buddhist literature, urge monks to uphold right con-

22 Lamotte, History of Indian Buddhism from the Origins to the Saka Era, 198-200.

23 T 1545, ch. 183, 918a-21b.

24 Buswell and Jaini, “The Development of Abhidharma Philosophy," at 112.

25 T 397, ch. 56, 337b.

26 D 27, Ka 176b-177b.

27 Nattier, Once Upon a Future Time, 240.

28 Tib.: bskal pa bzang po.

29 One kalpa consists twenty antarakalpas.

30 Sadakata, Buddhist Cosmology, 108. 
duct and be diligent in learning and practice in order to keep the Dharma from declining.

The Candragarbhasūtra mentioned above became very popular in Tibet. It does not only have an early Tibetan translation found in Dunhuang, ${ }^{31}$ but is also included in every edition of the Tibetan Buddhist Canon. In addition, the famous historian Bu ston (1290-1364) (2) $^{2}$ cited the entire text of the Candragarbhasūtra with only a very few abbreviations in his Chos 'byung ("History of Buddhism in India and Tibet"). ${ }^{33}$ In the bKa' thang literature the great treasure finders 0 rgyan gling pa (b. 1323), Sangs rgyas gling pa (1340-1396) and Padma gling pa (b. 1450) all reproduce the prophecy from the Candragarbhasūtra, which in its Khotanese adaptations predicts - instead of a flight to Kausāmbī, which was overrun by Muslims at the time an exodus to Khotan (Li yul in Tibetan). However, by the fourteenth century Khotan is no longer a safe haven for Buddhists, and the Li yul ("The Land of Li") mentioned in the prophecy then comes to be identified by Tibetans with Nepal. ${ }^{34}$

In Tibet there are three cosmological systems, the Abhidharma, the Kālacakra and the Great Perfection (rDzogs chen). ${ }^{35}$ Although these cosmological systems represent different approaches, they do not contradict each other in Tibetan thought. ${ }^{36}$ Nevertheless, the prophecies related to the Hidden Land of Yolmo reflect only the single world universe view of Abhidharma cosmology. Their descriptions of the Age of Decline are very similar to the main narrative of the Cakkavattisinanādasutta in emphasizing that as a result of society's moral decline, human lifespan is shortened, and at the end of the era people need to escape. The Candragarbhasūtra also exerted considerable influence; the external and internal signs of the End Times which it predicts are continuously re-interpreted and enriched to reflect contemporary events in Tibet. However, Tibetan texts emphasize that the escape from Tibet is necessary in order to avoid annihilation, and they also stress that the Dharma can be preserved only in Hidden Lands which support practitioners in attaining higher realizations. And instead of talking about slad ma'i tshe slad ma'i dus or the "latter times", they identify their present with the dus lnga brgya tha ma'i tshe, "the final (or most inferior) five-hundred-year period", when it is time to escape from Tibet.

31 Nattier, Once Upon a Future Time, 229. IOL J601.1.

$32 \mathrm{Bu}$ ston Rin chen grub was the abbot of the Zhwa lu Monastery and an important figure in the production of the foundations for many extant editions of the Tibetan Buddhist Canon.

33 See under Bu ston Rin chen grub, Chos 'byung gsung rab rin po che'i mdzod in the bibliography. 34 Sardar-Afkhami, The Buddha's Secret Gardens, 59, fn. 64. See Brough, "Legends of Khotan and Nepal," 333-339 for a comparison of legends related to Khotan and Nepal.

35 The Abhidharma and the Kālacakra are two cosmologies developed in India and later transferred to Tibet. The root text of the Abhidharma system is the Abhidharmakośa written by Vasubandhu in the fourth-fifth century CE and translated into Tibetan in the eighth century CE. The root tantra of the Kālacakra system was translated into Tibetan in 1027 CE. Instead of physical cosmology, Great Perfection is concerned more with primordial purity, the fundamental nature of being.

36 A fascinating exposition of these systems is presented by "Jam mgon kong sprul bLo gros mtha yas". The English translation of the text is included in Jamgön, Myriad Worlds. 


\section{Tibetan Treasure Texts on the Age of Decline Con- cerning the Hidden Land of Yolmo}

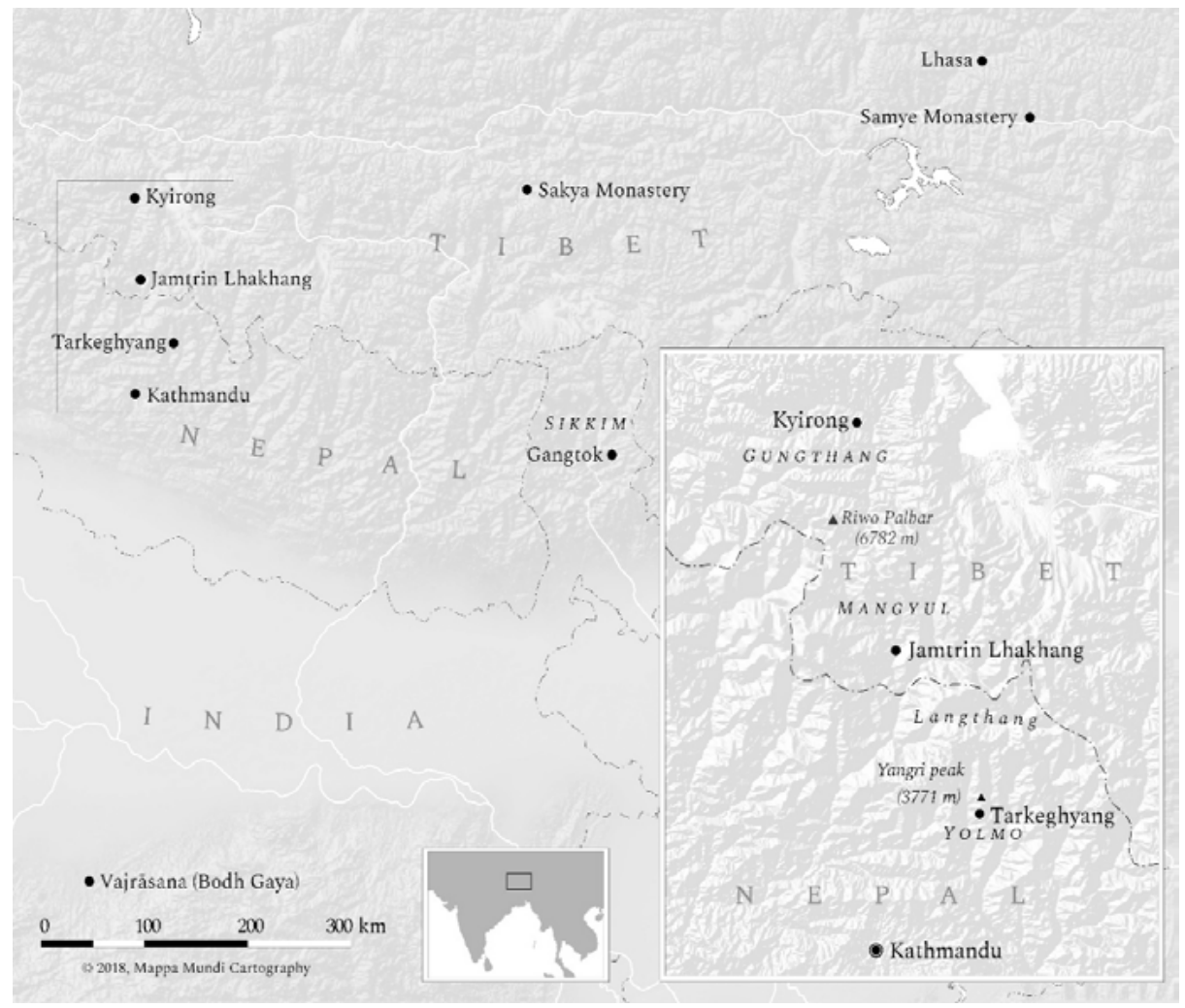

Fig. 1: Map of the Himalayan Asian region

The rNying ma School is considered to be the greatest exponent of the treasure tradition (gter lugs), ${ }^{37}$ and one of the rNying ma lineages, the Northern Treasure (Byang gter) founded by Rig 'dzin rGod ldem (1337-1408), became particularly famous for

37 However, "treasure transmission" is not exclusive to this school. Most traditional accounts consider Sangs rgyas bla ma, who lived in the eleventh century, to be the first treasure-revealer, but textual accounts show that the treasure tradition becomes popular only from the thirteenth century onwards. See Doctor, Tibetan Treasure Literature, 198, fn. 5; Thondup, "The terma Tradition of the Nyingmapa School," 154; Gyatso, "The Logic of Legitimation in the Tibetan Tradition," 99, fn. 5. Sangs rgyas bla ma is mentioned as the first treasure-revealer already by 0 rgyan gling pa (1323-ca. 1360) in his O rgyan guru padma 'byung gnas kyi skyes rabs rnam par thar pa rgyas pa bkod pa padma bka'i thang yig (Padma bka' thang shel brag ma), xylograph from blocks carved in 1966 in Rumtek, preserved at Nyishang Takashar Monastery in the Manang area of Nepal (n.p., 1972), f. 197a. 
promoting the concept of Hidden Lands. From the fourteenth century onwards, a wide range of literature developed in Tibet regarding the way to flee to the Hidden Lands, how to identify them, how to open the gate of the sacred place (called respectively lam byang, route manual; gnas yig, guide-book; and kha byang, inventory of treasures ${ }^{38}$ ), descriptions of how they look (gnas bshad), and accounts of what prophecies (lung bstan) were given regarding them.

The prophetic texts on Yolmo quoted here all belong to a collection called Byang gter lugs kyi rnam thar dang ma 'ongs lung bstan ("Biographies and Future Prophecies of the Northern Treasure Tradition"). ${ }^{39}$ It consists of altogether twentysix texts, twenty of them using gter tsheg, ${ }^{40}$ indicating that they belong to revealed treasures (gter ma). The other six texts were composed by different authors and include a supplication prayer, biographies and other works. The copy used for the 1983 edition by the publishers in Gangtok was borrowed from the library of Lama Sengge of Yolmo. Five of the twenty-six texts of this collection are dedicated solely to the Hidden Land of Yolmo Snow Enclosure, and one is a general description of Hidden Lands, Sbas yul spyi'i them byang, which mentions Yolmo frequently. These six texts were included among other Tibetan sources in another collection published by one of the Yolmo lamas, mKhan po Nyi ma don grub (KNYD) ${ }^{41}$ in Kathmandu in 2003, and the Sbas yul spyi'i them byang was also published in another collection of texts regarding the Hidden Land of 'Bras mo gshongs (Sikkim). ${ }^{42}$ All of the six texts are regarded to be hidden treasures, and the colophons of four texts mention that that particular "treasure" (gter $m a$ ) was extracted at the middle ${ }^{43}$ of the northern side of the sacred mountain Zang zang lha brag by Rig 'dzin rGod ldem. ${ }^{44}$ One colophon says that the text was hidden in the middle of a rocky mountain that looks like a heap of poisonous snakes, ${ }^{45}$ and another simply states that it is a prophecy given by Padmasambhava. ${ }^{46}$ Zang zang lha brag is located in the Northern Plain in Tibet (Byang thang). In 1366 Rig 'dzin rGod ldem discovered a

38 A synonymous term is gter gyi lde'u mig, "key to the treasures”. It contains a list of locations where treasures are found.

39 Biographies and future prophecies of the Northern Treasure tradition, ed. Gyalsten and Dawa.

40 In the treasure texts of rNnying ma literature gter tsheg, or "treasure sign" is used instead of the shad (interpunctuation-marker).

41 The book includes six works by Rig 'dzin rGod ldem, two short texts by Bya bral Rin po che and a longer piece by mKhan po Nyi ma don grub.

42 Ma 'ongs lung bstan sbas yul gyi them byang, ed. Buddhist Digital Resource Center.

43 Tib. sked, meaning literally the "waist" of the mountain.

44 Sbas yul spyi'i them byang, ed. Dondrup; Yol mo'i snying byang, ed. Dondrup; Yol mo gangs ra'i gnad byang, ed. Dondrup; Yol mo gangs kyi ra ba’i lung byang snying gi tikka, ed. Dondrup.

45 Yol mo'i gnad yig, ed. Dondrup, 27: brag ri sdug sbrul spungs 'dra. A sacred place beneath Mount Bkra bzang where Rig 'dzin rGod ldem made his second treasure discovery. The same text is quoted by the 6th Zhwa dmar pa, who did a pilgrimage to the sacred places of Yolmo in 1629. See Lamminger, "Der sechste Zhva dmar pa Chos kyi dbang phyug."

46 Sbas pad ma tshal gyi lam yig, ed. Dondrup. 
blue chest there with compartments filled with yellow parchments. The lineage he founded was named "Northern Treasure" after this discovery. The groups of texts were designated by their position, and the five groups (four in the cardinal directions and one in the centre) were named the "Five Treasuries". From the dark brown central cavity, Rig 'dzin rGod ldem extracted his most important revelation, the Kun bzang dgongs pa zang thal ("Penetration of the Intention of Samantabhadra"), which became the central teaching of the Northern Treasure tradition. This gter ma - a rDzogs chen text - was also practiced by the 5th Dalai Lama (1617-1682) and is an important teaching of the rNying ma school even today. According to his biographer, ${ }^{47}$ Rig 'dzin rGod ldem was entrusted with another set of treasures by an old hermit living on Mount Bkra bzang called Ri khrod pa bZang po, ${ }^{48}$ who, guided by dreams and visions, excavated treasures buried under the threshold of the temple of Grom pa rgyang in gTsang. ${ }^{49}$ This set of texts contained the famous Gsol 'debs le'u bdun $m a,^{50}$ an important prayer attributed to Padmasambhava and said to be concealed by $\mathrm{Mu}$ khri bTsan po, ${ }^{51}$ destined to protect and reinvigorate the royal line during the time of degeneration. There were also many minor prophecies, certificates and keys (list of locations) to Hidden Lands among the texts, one of them ${ }^{52}$ predicting that the treasure master (gter ston) will have vulture feathers growing on the crown of his head..$^{53}$ According to the text, the protector of the treasures (gter tshab) was to be the king of Gung thang, but by the time Rig 'dzin rGod ldem received the treasures, King bKra shis lde had died. ${ }^{54}$ His son, Phun tshogs lde (13381370) lived in the Sa skya Monastery, and Rig 'dzin rGod ldem visited him, offering him to assume the place of his father as the treasure's protector. However, the young prince and the scholars of Sa skya as residents of a prestigious monastic institution did not look favourably on a village Tantric practitioner like rGod ldem. Apart from the political turmoil of the fourteenth century, with the emergence of wealthy monastic hegemonies like Sa skya, the Old School (rNying ma tradition) with its village-based lay tradition usually centred around a clan patriarch, where the teaching was passed down from father to son, faced a cultural and religious cri-

47 Nyi ma bzang po, a late disciple of Rig 'dzin rGod ldem. See BDRC ID: P8839. The biography titled sPrul sku rig 'dzin rgod ldem 'phru can gyi rnam thar gsal byed nyi ma'i 'od zer is also available on the BDRC website under W27603.

48 Also mentioned as gTer ston bZang po grags pa.

49 It is one of the mtha' 'dul temples erected in order to suppress the left hip of the demoness. See Sørensen, The Mirror Illuminating the Royal Genealogies, 276-277.

50 See the original text and its English translation at http://www.lotsawahouse.org/topics/leudunma/.

$51 \mathrm{Mu}$ khri btsan po, one of the sons of King Khri srong lde btsan.

52 The title of the text is Snying tig gnad kyi man ngag don bdun. It is included in the collection of the Biographies and Future Prophecies of the Northern Treasure Tradition. W27866: 277-302.

53 This refers to Rig 'dzin rGod ldem, who was born with moles on the top of his head which caused the hair on his crown to look like feathers. His name rgod ldem means "vulture feather".

54 He ruled Gung thang between 1352 and 1365. 
sis. And while the New Schools (Sa skya, bKa' brgyud, and later the dGe lugs pa) followed the New Tantras of Bengal, the teachings of the Old School were centred around the Tantras from Oḍḍiyāna and the person of Padmasambhava. According to Rig 'dzin rGod ldem's biography, he was able to generate faith in Phun tshogs lde only by performing a wrathful Vajrakilaya (Tib. rDo rje phur pa) rite, but even then, the new king offered only one $z h o^{55}$ of gold for his treasure hunt. Rig 'dzin rGod ldem managed to excavate the treasures, a number of guidebooks among them, and meditated for a year with his uncle on the top of Mount Bkra bzang on their meaning. ${ }^{56}$ After a difficult fourteen years exploring the Hidden Land of 'Bras mo gshongs, Rig 'dzin rGod ldem finally managed to hand over the treasures to the new king of Gung thang, mChog sgrub lde, who released a royal declaration in 1389 about establishing a patron-priest relationship (mchod yon) with Rig 'dzin rGod ldem and his lineage "for as long as the Buddhist teaching lasts". He donated to Rig 'dzin rGod ldem and his descendants the Ri bo dPal 'bar' ${ }^{57}$ and three Hidden Lands under his sovereignty including their monasteries, hermitages and nomad pastures. $^{58}$

\subsection{The Time to Leave Tibet}

The gter ma texts concerning Yolmo unearthed by Rig 'dzin rGod ldem are all written in dialogue form, similar to the teachings of the Buddha. However, in treasure literature the teacher is usually not Sākyamuni but Padmasambhava, the Indian Tantric master considered to be the second Buddha by Tibetans. He is represented as talking with his disciple Khri srong lde btsan (c. 742-798), the Bodhisattva King of Tibet who, according to rNying ma literature, was the most popular ruler of the glorious Tibetan empire which lasted from the seventh to the eleventh centuries.

The frame narrative is set in bSam yas, the first monastery of Tibet. The king invites Padmasambhava, who is meditating in the nearby mChims phu hermitage, ${ }^{59}$ in order to ask him about the Age of Decline and about historical events indicating the advent of the last five hundred years, when it will be time to escape from Tibet.

55 One zho is approximately one tenth of an ounce of gold.

56 Sardar-Afkhami, “The Buddha's Secret Gardens,” 69-75.

57 A mountain dominating the sKyid rong valley, around $6500 \mathrm{~m}$ high.

58 Herweg, "The Hagiography of Rig 'dzin Rgod kyi ldem 'phru can and three Historic Questions Emerging from It," 128-133.

59 The mChims phu hermitage is about $16 \mathrm{~km}$ northeast of bSam yas Monastery. According to legend, Padmasambhava bestowed the first Vajrayāna initiation to his eight disciples in one of its caves and gave several teachings there to his twenty-five disciples. The caves today are named after famous yogis who meditated there, one of them being 'Jigs med gling pa (1729-1798), who received the kLong chen snying thig transmission there. 


\subsubsection{External Signs}

Padmasambhava's prophecy - similarly to the early Indian sources discussed above - emphasises foreign invasion as the main sign showing that the end of times is drawing close. The Mongols and the Turks are frequently mentioned as invading armies, but these presumably historical events are varnished with so many layers of Buddhist mythology that it is impossible to separate prediction and mythology from historical fact. In a way, this perfect amalgamation is what makes the prophecies work, because it makes them easily identifiable with various historical events of different historical periods. For instance, it says in the Sbas yul spyi'i them byang: "Māra, the Lord of Pleasure, ${ }^{60}$ when looking from the top of Mount Meru in the four directions [and seeing] the general victory of the dark side, will rejoice. Seeing that the teaching of the Sākya is degenerating in the southern Jambudvīpa, Māra will be cheerful. That time Vajrāsana ${ }^{61}$ in India will be captured by the Turks, ${ }^{62}$ and Māra will throw flower-weapons". ${ }^{63}$ At another point the same text notes: "Tibetans all will be defeated by foreign invasion and the Turks." ${ }^{44}$ Similarly, the Yol mo gangs ra'i gnad byang ("Essential Guide to the Yolmo Snow-Enclosure”) states:

At the end of times, escape the suffering tormenting Tibet! When India and Tibet, the Land of Snow, will be conquered by Māra's army, the Turks, there is a safe valley west of Mangyul and east of Nyanam, between them. Its upper part is cut off by snowpeaks, the lower part by jungle. ${ }^{65}$

60 Dga' rab dbang phyug, the chief Māra, the Love God, Kāma. Māra (bDud) in Buddhist mythology is a powerful god, who dwells in the highest abode in the desire realm. For the Dharma practitioner, he symbolises one's ego-clinging and preoccupation with the eight worldly concerns.

61 Rdo rje gdan, the place where Gautama Siddhārtha attained enlightenment. It is identified with today's Bodh Gayā.

62 Du ru kha. This event, when Du ru kha rgyal po destroyed the shrine of Rdo rje gdan, is part of the mythic history of the black flying bse mask of the Sa skya pa. See Sørensen and Hazod, Thundering Falcon, 284 and Vitali, "Sa skya and the mNga' ris skor gsum Legacy," 26-27. Sbas yul spyi'i them byang, ed. Dondrup: 3. de'i tshe bdud dga' rab dbang phyug gis/ ri rab kyi rtse nas phyogs bzhir bltas pas/ phyir nag po'i phyogs kha rgyal nas bdud brod pa skyed lho phyogs 'dzam bu gling pa shākya'i bstan pa nyams pa mthong pas/ bdud snying dga'/ de'i dus na rgya gar rdo rje gdan du ru khas 'dzin pas bdud mtshon cha'i me tog 'thor/

63 Sbas yul spyi'i them byang, ed. Dondrup, 3: de'i tshe bdud dga' rab dbang phyug gis/ ri rab kyi rtse nas phyogs bzhir bltas pas/ phyir nag po'i phyogs kha rgyal nas bdud brod pa skyed lho phyogs 'dzam bu gling pa shākya'i bstan pa nyams pa mthong pas/ bdud snying dga'/ de'i dus na rgya gar rdo rje gdan du ru khas 'dzin pas bdud mtshon cha'i me tog 'thor/

64 Sbas yul spyi'i them byang, ed. Dondrup, 5: bod kyi mi thams cad mtha' dmag dang du ru kas brlag.

65 Yol mo gangs ra'i gnad byang, ed. Dondrup, 29: dus tha ma la bod sdug bsngal gyis nyams thag pa rnams der bros shig/ de nas rgya gar dang bod kha ba can gyi yul bdud dmag du ru kas btul ba'i dus na/ nub mang yul la gtad pa/ shar gnya' nam la gtad pa'i bar na phu gangs kyis chod pa/ mda' nags kyis chod pa'i lung pa btsan po gcig yod do/ 
The same text, when praising the Hidden Land of Yolmo, says: "It is free of the danger of the Mongolian army and the Turks." 66

At one point the Sbas yul spyi'i them byang provides slightly more detailed historical guidance:

In Tibet the power of the great king will weaken, and the law will perish. One-hundred and twenty-three years will pass in Tibet without [central] power. Then, the Mongolian Black Mudur (Mu dur nag po) will conquer [Tibet]. One hundred and twenty-five years of Mongolian rule follow. Then the Mongolian rule will perish. Then Tibetans should go to hidden lands. ${ }^{67}$

And later in the same text again: "In Tibet, first, the name of Māra's son will be Go rta nag po."68 It is difficult to identify Mu dur nag po, but from the line of events it is safe to assume that the second name, Go rta nag po, is a misspelling of rDo rta nag po, who appears in many other Tibetan sources as one of the generals of the Mongolian army that invaded Tibet in 1240 ("Iron-Male-Mouse Year"). ${ }^{69}$ After this military campaign the Sa skya school was invested with temporal authority over Tibet by the Mongols, and when Kublai Khan ascended to the throne of China in 1280, the lamas of Sa skya became the preceptors of the Yüan emperor. In spite of his teacher 'Phags pa's protest, Kublai did not want to tolerate any other school than the Sa skya pa. When the Yüan Dynasty fell in 1368, Rig 'dzin rGod ldem was thirtyone years old and had already revealed some important treasures.

The Yolmo gangs ra'i gnad byang ("Essential Guide to the Yolmo Snow-Enclosure") refers to an attack on Nepal: "Later, when Nepal is approached by the army of the Turks, [and they stay there for] three years, you must go to the Pu'i li Healing Lake, the land of herbs. ${ }^{70}$ Then the time will arrive to capture the land [of Yolmo]." ${ }^{\text {11 }}$ This is the only mention of Nepal being attacked by the Turks, and it can be identified with a historical event, the time when Shansud-Din Iliyas invaded the Kath-

66 Yol mo gangs ra'i gnad byang, ed. Dondrup, 31: hor dmag du ru ka’i dmag gis 'jigs pa las grol lo/ 67 Sbas yul spyi'i them byang, ed. Dondrup 1-2: bod du mnga' bdag rgyal po'i mnga' thang nyams nas khrims 'jig/ bod la khrims med lo brgya dang nyi shu rtsa gsum yong/ de nas mu dur nag po hor gyis 'dul/ hor khrims lo brgya dang nyi shu rtsa lnga yong/ de nas hor khrims 'jig/ de'i dus su bod sbas pa'i yul du 'gro dgos/

68 Sbas yul spyi’i them byang, ed. Dondrup 2: bod du dang po bdud kyi bu go rta nag po bya ba 'byung/

69 See Dudjom, The Nyingma School of Tibetan Buddhism, 766; Stein, Tibetan Civilization, 78; Shakabpa Tibet. A Political History, 61. Childs, "Refuge and Revitalization," 133. Some scholars assume that the names $\mathrm{Mu}$ dur nag po and rDo rta nag po refer to the same person; see Sardar-Afkhami, "The Buddha's Secret Gardens," 41, fn. 52.

70 I requested mKhan po Nyi ma don grub to clarify this place name. According to him, it refers to the upper part of Yolmo in general.

71 Yol mo gangs ra'i gnad byang, ed. Dondrup, 32: dus phyi bal po'i yul du du ru ka'i dmag lhags pa dang/lo gsum phu'i li sman mtsho sman gyi yul du 'gro dgos pa yang yong bas/ dus la babs pa'i tshe yul zungs shig/ The Tibetan word sman also has other meanings, it can, for instance, refer to a class of spirits, and the expression phu'i li sman mtsho sman gyi yul can also be translated as "[you must go] to the Pu'i li lake of the sman, to the land of sman." 
mandu valley in 1349 with his Turkic army. ${ }^{72}$ Curiously enough, it seems that Tibetans are urged by the prophecy to capture borderland areas at a time when Nepal is busy with foreign invasion.

A major event prophesied as a sign of the coming of the End Times is the murder by knife of three kings of Mang yul Gung thang. The Sbas yul spyi’i them byang says:

Oh, great king! When one king of Mang yul Gung thang's line is stabbed with a knife, suffering will start in Upper Tibet. With a second death by stabbing, disaster will start in Tibet. With the third murder, the happiness of Tibet is gone: flee to the hidden lands and southern valleys. At that time, those who make it to the hidden lands will find peace. ${ }^{73}$

Rig 'dzin rGod ldem's biography mentions that King Phun tshogs lde (1338-1370) was murdered with a knife, ${ }^{74}$ and quotes several prophecies from earlier texts stressing that the power and faith of the royal lineage is weakened. Because the fate of Tibet depends on the royal descendants of Gung thang, it is important to unearth the treasures in order to protect the royal line and the whole of Tibet. ${ }^{75}$ Similarly, in the Yol mo'i gnad yig ("Essential Instructions of Yolmo Snow-Enclosure") Padmasambhava gives the following prediction to King Khri srong lde btsan: "When the royal lineage reaches its end in Mang yul Gung thang, the dividing line between happiness and suffering is reached. Obtain the treasure (gter) protecting Tibet from suffering!"76 Western scholars sometimes interpret this prophecy as a reference to the fall of the Gung thang Kingdom in $1620 .^{77}$

The third sign of the End Times is that the royal temples built during the imperial era to pin down the supine demoness lying on the land of Tibet are deserted and in ruins. ${ }^{78}$ As the Sbas yul spyi'i them byang says:

Earlier, according to the Teaching, the signs of the end were inconceivable, particularly those signs which show the need to go to the hidden lands. In the temples you established, great king, and the other two kings with an awakened mind, ${ }^{79}$ most of the worship will cease, they

72 Childs, "Refuge and Revitalization," 136; Regmi, Land Tenure and Taxation in Nepal, 312-322. 73 Sbas yul spyi'i them byang, ed. Dondrup, 14: kye rgyal po stod mang yul gung thang du rgyal po nyid kyi gdung rgyud gcig gri ru bkum pa dang bod kyi sdug 'go 'dzugs so/ gnyis gri ru bkum pa dang bod kyi phung 'go 'dzugs so/ gsum bkum pa dang bod kyi skyid pa zad pas sbas yul dang lho rong la bros shig/ de'i dus su sbas pa'i yul du thar pa rnams la bde skyid 'byung ngo/

74 Sardar-Afkhami, "The Buddha's Secret Gardens," 76. Herweg, "The Hagiography of Rig 'dzin Rgod kyi ldem 'phru can,” 109.

75 Herweg, "The Hagiography of Rig 'dzin Rgod kyi ldem 'phru can,” 106-110.

76 Yol mo'i gnad yig, ed. Dondrup, 23: rgyal po nyid kyi gdung rgyud tha ma la mang yul gung thang du 'byung/ de'i dus su bod kyi bde sdug go so mtshams su song bas/ bod kyi sdug bsngal skyob pa'i gter'di thob par 'gyur ro/

77 Childs, "Refuge and Revitalization," 142; Regmi, Land Tenure and Taxation in Nepal, 312-322.

78 For a beautiful image of the supine demoness with the list of temples built on her body, see Sørensen and Hazod, Thundering Falcon, 399.

79 The three Dharma kings who established Buddhism in Tibet: Srong btsan sgam po (569-649?/ 605-649?), Khri srong lde btsan (r. 755-797 or 804) and Ral pa can (806-838). 
will be torn down. In half of the Border Taming ( $m$ tha' 'dul) and Further Taming temples (yang 'dul $)^{80}$ worship will stop. In 'On chang rdo $^{81}$ a royal emanation will establish a temple in two generations from now. Three hundred and sixty years after the foundation, it will be in ruins and deserted..$^{82}$

Beside these events, floods, earthquakes, fires, famine, and religious repression are also mentioned as signs indicating that it is time to leave Tibet and find refuge on the borderlands in a Himalayan Hidden Land.

\subsubsection{Internal Signs}

The internal signs of the approaching final five-hundred-year period are the moral decline and disintegration of society, when disturbing emotions poison people's hearts, and the only way to escape the resultant violence is to flee to a Hidden Land. The Sbas yul spyi'i them byang portrays this period in the following way:

The king of Māras will fire seven arrows to Tibet from the top of Mount Meru. As a result, there will be no sun and moon, [and therefore] no year and month on Jambudvipa. As an external sign, dazzling fire will blaze on the sky. As an internal sign, district chiefs, army commanders, local lords, the ones with greater karmic power are shot by the poison of Māra that makes them kill (gsod byed kyi dug). Instantaneously, burning hatred and wild jealousy will arise. As a result of this, they will kill each other, completely annihilate each other.

Because powerful scholars, spiritual masters, and teachers are shot by the arrow poisoned with delusion (smyo byed dug $m d a^{\prime}$ ), instantaneously they will feel despair, and become coldhearted. At that time those who generate mind for practice disparage each other. They turn away from the Dharma and engage in worldly activities. They turn away from practice and rely [only] on words. Half of the country is filled with [people] wearing yellow robes. ${ }^{83}$ There are only a few following the Buddha's words.

The ministers and advisors will be shot by the poison of warfare ('khrug byed kyi dug). Instantaneously, they become disloyal. As a result, their mind will get confused and want to do even greater wrongs. Rumours not told by some to others, they reveal. Advice that others did not want to give, they will allow.

There is chaos and civil war in Tibet, and the poison of craving for food (lto ba'i dug) will be shot at the men. Tibetan religious men, and [those] not at all religious, and the ones in between, are all barely able to handle the pain. Suddenly steaming hot food appears [in their

80 Mtha' 'dul dang yang 'dul gyi gtsug lag khang.

81 King Ral pa can built a temple there, in the lower sKyid chu valley. See Dudjom, The Nyingma School of Tibetan Buddhism, 522.

82 Sbas yul spyi'i them byang, ed. Dondrup: 1-2: gong du bstan pa bzhin du mtha' ma'i rtags bsam gyis mi khyab bo/ khyad par sbas pa'i yul du 'gro dgos pa'i rtags 'di ltar 'byung/ rgyal po nyid la sogs pa rgyal po byang chub sems ldan gsum gyis bzhengs pa'i lha khang gi mchod pa chag phal cher zhig ral du song/ mtha' 'dul dang yang 'dul gyi gtsug lag khang phyed zhig/ mchod pa 'bul ba rgyun chad 'on chang rdo'i sa phyogs su sprul pa'i rgyal po gcig gis da ste gdung rabs gnyis nas lha khang bzhengs par 'gyur ro/ de bzhengs nas mi lo sum brgya drug cu nas zhig ral du stong par 'gyur/

83 People pretending to be monks. 
mind], and the lust of eating will arise in everyone. They hunt for deer ${ }^{84}$ of the higher remote places. They catch fish with arrows. They slaughter their own cattle. They eat red meat. They drink red blood. They put on animal skin. In the End Times ${ }^{85}$ they will eat the flesh of [their own] father. ${ }^{86}$

Women are shot with the poison of deceit (g.yo byed kyi dug). Instantaneously, their minds become dark and calculating. As a result, they spread bad rumours and slander; fathers and sons quarrel. There will be discord among the local people, masters and servants will disagree, and there will be feud in the family.

When the evil-minded are shot by the arrow of evil actions and deluded mind (las log blo rgyugs kyi $m d a^{\prime}$ ), instantaneously obsessive greed and craving arises. At that time suddenly people will be killed and robbed of their wealth. They pull out a knife from under the robe. Women will be killed with knives, strangled, their hair pulled out, and heads trashed. Some are buried alive in secret.

Then the poison of killing and stealing life (srog gcod tshe 'phrog gi bdud) will be shot on spiritual masters, great practitioners and righteous leaders. The virtuous ones will suddenly feel unhappy and empty. At that time even the root of virtue that was left will be completely wiped out. This is how the seven poisonous arrows of Māra will be shot on Tibet.

Like a small bird carried away by a hawk, Tibetans are not able to focus their thoughts on the same thing but argue with each other. They attack each other and fight, [and this] will last for thirty years. At that time, the virtuous ones, possessing the thought of enlightenment, ${ }^{87}$ those having determination and physical strength, an entourage and provisions, if they look for the road and seize the land, by possessing skilful means and recognising favourable circumstances, they will capture all the hidden lands. Border armies and Turks will not be able to massacre these Tibetan people. ${ }^{88}$

84 Ri dvags. Herbivores, such as deer.

85 Dus tha mar, referring to the final five hundred years.

86 Cannibalism.

87 Skt.: bodhicitta.

88 Sbas yul spyi'i them byang, ed. Dondrup, 3-5: de'i tshe bdud dga' rab dbang phyug gis/ ri rab kyi rtse nas phyogs bzhir bltas pas/ phyir nag po'i phyogs kha rgyal nas bdud brod pa skyed lho phyogs 'dzam bu gling pa shākya'i bstan pa nyams pa mthong pas/ bdud snying dga'/ de'i dus na rgya gar rdo rje gdan du ru khas 'dzin pas bdud mtshon cha'i me tog 'thor/ bod kha ba can gyi yul du bstan pa'i lhag ma dar la ma smin ba'i dus 'ongs te/ bdud kyi rgyal po des ri rab kyi steng nas dug mda' bdun bod la 'phen te/ de la lo zad zla zad nyi zla'i mdangs 'dzam bu'i gling la med pa'i tshe 'phangs pas/ phyi rtags su ni nam mkha' la me 'od lam lam pa 'ong/ nang rtags su sde dpon dang/ dmag dpon dang/gtso bo dang/ 'jig rten gyi las stobs che ba rnams la gsod byed kyi dug 'phangs pas/glo bur du zhe sdang tsha lam lam pa dang phrag dog 'khrug ram ram pa skye/ de'i rje su gcig gis gcig gsod/gcig gis gcig brlag par 'joms so/ mkhan po slob dpon ston pa/ stobs che ba rnams la smyo byed dug mda' phog pas/glo bur du snying mi dga' ba dang/ snying grang lhang lhang pa 'ong/ de'i dus su chos byed la sems zhugs te/gcig gis gcig smod/ chos bor nas 'jig rten gyi las la 'jug/nyams len bor nas tshig la ltos/gos ser mo gon pas yul phyed khengs/ ston pa'i bka' bzhin pa re re tsam/ 'khrug byed kyi dug blon po dang gros byed la phog pas/shes pa rtsi phun pa glo bur du skye/ de'i rjes su blo 'phrul khong skyon che bar'dod pas pha rol la mi smra ba'i gtam tshur smra/ tshur rol mi 'dod pa'i gros phar slob/ bod nang 'khrug la zing 'gro/ rngam char lto ba'i dug shar po la phog ste/ bod kyi chos pa dang mi chos pa 'bring po thams cad la kha ngal khyog khyog pa/ lto ba tsha chil chil ba glo bur du 'byung/ de'i dus su thams cad la zas skom gyi 'du shes 'dod sred langs ste phu'i ri dwags rngon/ mda'i nya 'dzin/ rang gi phyugs 'og tu bcug ste gsod nus/ sha dmar po za/ khrag dmar po 'thung/ pags pa dmar po 'ding/ dus tha mar pha sha za ba 'byung ngo/g.yo byed kyi dug bud med la phog ste/glo bur du shes 
Similar descriptions of varying length can be found in many prophetic texts urging people to move to Hidden Lands. One of the treasure texts giving the longest depiction of the chaotic state of society and morals is the mChod rten chen po bya rung kha shor gyi lo rgyus thos pas grol ba ("Legend of the Great Stupa"), ${ }^{89}$ unearthed in bSam yas by the same treasure master, sNgags 'chang Sākya bZangpo, who opened the Hidden Land of Yolmo in the early sixteenth century.

\subsection{Finding the Hidden Land}

The guidebooks, inventories and keys to the Hidden Land of Yolmo give a detailed description of the terrain, the number of peaks and valleys, as well as the local guardians and mountain gods who should be propitiated by the newcomers. They provide information regarding the season during which the land is accessible, which routes lead there, and what kind of dangers can be expected on the way. They also discuss the number of people and the skills necessary to complete the arduous journey. The descriptions sometimes sound like precise instructions for travellers, sometimes like symbolic, dreamlike images suitable only for the spiritually advanced. The sBas pad ma tshal gyi lam yig ("Guide to the Lotus Grove”) says:

If you look from bSam yas one-two yojana ${ }^{90}$ far to the southwest, Yolmo Snow Enclosure shall be [there]. It is also called the Hidden Lotus Grove. Its features are a summit gathering six upland valleys; three connected valleys on the slopes of high snow mountains. It is north of Bodh Gayā, northeast of the city of $\mathrm{Li}^{91}$ below Mang yul. ${ }^{92}$ It is on a hillside of Buddha Sāakyamuni's Lay Follower, ${ }^{93}$ on the western slope of the Chief of the Twelve Goddesses. ${ }^{94}$ You can see Li

pa rtsi ru ma 'ong/ de'i rjes su phra ma mang po smra ste pho dang bu 'thab tu 'jug/yul mi nang 'thab/ dpon dang g.yog 'khon/ pha spun nang dme byed pa gcig 'ong/las log blo rgyugs kyi mda' blo ngan la phog nas glo bur du rngam sems hab khyur ba skye/ de'i tshe glo bur du mi gsod nor 'khyer/ chos gos kyi 'og nas gri 'dzugs/ bud med gri ru 'chi/ dbugs ma chad par 'bal dang mgo rdung byed/ gson po sa rdibs su bskung ba gcig 'ong/ srog gcod tshe 'phrog gi bdud dge ba'i bshes gnyen chos byed dang sde dpon ya rab la phog ste/ dge byed la glo bur du snying tsha stong stong pa 'ong/ de'i dus su dge ba'i rtsa ba ci yod pa mthar mi thon par 'chi/ de ltar bdud kyi dug mda' bdun bod la phog pa dang/ bya phran khras khyer ba ltar/ bod kyi bsam pa phyogs gcig tu mi 'dril bar gcig la gcig rtsod/ gcig la gcig rgol zhing 'khrugs pas/ mi lo sum cu bar du gnas so/ de'i dus na dge byed byang chub kyi sems dang ldan pa/ snying rus lus stobs che ba/ 'khor dang yo byad ldan pa/ thabs dang rten 'brel mkhas pas lam btsal yul bzung na sbas pa'i yul thams cad zin no/ bod kyi mi thams cad mtha' dmag dang du ru kas brlag cing gsod par mi nus so/

89 mChod rten chen po bya rung kha shor gyi lo rgyus thos pa grol ba. W00KG09761: 9-54.

90 Measure of distance used in ancient India. Scholars estimate that one yojana was equivalent to c. $8-12 \mathrm{~km}$.

91 Kathmandu in this case.

92 sKyid rong valley, Southern Tibet.

93 It refers to dGe bsnyen gLe ru, one of the great mountains and its mountain god.

94 Bstan ma bcu gnyis, the twelve goddesses of Tibet. 
$\mathrm{yul}^{95}$ from there [i.e., from Yolmo]. At the time when people live until sixty, the path is found, and when the lifespan is about fifty, settlements are established, which turn into seven thousand bigger cities. $^{96}$

\section{And the Yol mo'i snying byang ("Quintessential Inventory of Yolmo”) says:}

[The place] called Yolmo Snow Enclosure is below Mang yul, northeast of the city of Li, south of the snow mountain that looks as if a victory banner is stuck into it, west of the Snowy Yaksha Queen. ${ }^{97}$ There are three big valleys. There are three sub-valleys. It takes four days [to travel from the] upper to the lower parts of the valley. There are seven great treasures. Various kinds of herbs grow there. There is healing water in the middle ${ }^{98}$ of the land. In the upper part of the valley there is an eightfold glacial stream. There are three big lakes. There are many dākinīs $^{99}$ and local guardians residing there, therefore bad smell and impurity should be avoided. This place is very fortunate; therefore, longevity, merit, and wealth are in abundance. In the age of dregs obey the command and search for this land! ${ }^{100}$

\subsection{Righteous Rule and Ideal Society}

Geoff Childs has suggested that the primary purpose of Hidden Lands was the preservation of Tibet's imperial lineage by providing a place of refuge for the descendants and patrilineal kin of Emperor Khri srong lde btsan at times when the continuity of the lineage was threatened. ${ }^{101}$ He supported his theory by citing examples from Tibetan texts regarding five Hidden Lands: gNam sgo zla gam (Langtang),

95 Refers to Nepal, the Kathmandu valley.

96 Grong khyer: city, town, big settlement. In Tibet, even settlements with 30-40 houses are called grong khyer. According to mKhan po Rang grol (verbal communication, 2013), a place can be called grong khyer if it has at least eighteen workshops like blacksmith, etc. Sbas pad ma tshal gyi lam yig, ed. Dondrup, 20-21: bsam yas nas lho nub tu btsal ba'i dpag tshad gcig gnyis na/ yol mo gangs kyi ra ba zhes kyang bya/ sbas pa padma'i tshal zhes kyang bya ba gcig yod de/ de'i bkod pa ni/ phu drug 'dzoms pa'i yang rtse/ lung pa gsum gyi 'dzoms/gangs mthon po'i mgul/ rdo rje gdan gyi byang/grong khyer li'i byang shar/mang yul gyi gting/ thub pa chen po nyid kyi dge bsnyen gyi mgul/ bstan ma bcu gnyis kyi gtso mo'i nub mgul na yod do/ li yul mthong ba'i sa/ drug cu kha ral la lam rnyed/ Inga bcu'i dus su yul 'debs/ grong khyer bdun stong chags so/

97 Gnod sbyin gangs kyi rgyal mo. Name of a mountain.

98 Sked, literally "waist".

99 Tib. $m k h a$ ' 'gro $m a$, "sky-goer", female spirit.

100 Yol mo'i snying byang, ed. Dondrup, 28. yol mo gangs kyi ra ba zhes bya ba/ mang yul gyi gting/ grong khyer li'i byang shar/ gangs ri rgyal mtshan gtsugs pa 'dra ba'i lho/ gnod sbyin gangs kyi rgyal mo'i nub na/ lung pa chen po gsum yod/ lung phran gsum yod/ lung pa'i phu mda' la nyin lam bzhi yod/gter kha chen po bdun yod/sman gyi rigs sna tshogs skye ba yod/lung pa'i sked na sman chu yod/ phu na gangs chu yan lag brgyad ldan yod/ mtsho chen po gsum yod/ mkha' 'gro zhing skyong mang po gnas pa yod pas/ thab gzhob 'khon grib la 'dzoms/gnas 'di shin tu bkra shis shing/tshe dang bsod nams longs spyod thams cad rgyas par 'gyur ro/ snyigs ma'i dus nga'i bka' bzhin bsgrub pa rnams/ gnas 'di tshol cig/

101 Childs, Refuge and Revitalization. 
Yol mo gangs ra (Yolmo), sKyid mo lung (near Kutang), 'Bras mo ljongs (Sikkim), and mKhan pa ljongs (in Bhutan and Khumbu), and interpreted parts of Padmasambhava's prophecies as referring to specific historical and political events. ${ }^{102}$ Whilst my research on Yolmo has led me to agree with many of Childs' observations, I would like to stress that, according to the texts examined here, the protection of the royal line of Gung thang is entrusted to treasures (bla gter) and treasure masters (gter ston), and that there is no textual evidence that the royal line should be preserved by relocating its descendants to the Hidden Land of Yolmo.

Out of the six prophecies concerning Yolmo, four mention the importance of a king. As the relevant passages are brief, I will quote them in full:

'For going to the hidden lands, a Dharma-protecting king is necessary. ${ }^{103}$

'When there is no king, it is like having limbs without a head.'104

'In order to subdue the land, the king should be born in the Year of the Ox, Dragon or Tiger; the queen in the Year of the Sheep, Monkey or Bird; the ordained monks should possess knowledge, discipline, and kindness, all three. The Tantrika should keep his samaya, ${ }^{105}$ the Bon po should not offend the gsas ${ }^{106}$, and thirteen laymen possessing great physical strength should be present. They should [all] live in harmony, and the kingdom should be governed in accord with the Dharma. 107

'It is very important for the king to have an awakened mind, the queen to have pure conduct, the Bon po not to offend the gsas, and the Tantrika to have transmission. ${ }^{108}$

'In order to take hold of that land [Yolmo], the king must be of the Year of the Ox. [If so,] take it from the north. The queen should be of the Year of the Bird, [if so,] take it from the west. The preceptor should be learned in the Tripițaka, [if so,] take it from the east. The Tantrika should be firm in the developing stage [if so,] take it from the northeast. The Bon po should be someone not offending the gsas, [if so,] take it from the northwestern direction. The minister should be competent in making arrangements, [if so,] take it from the nearby surroundings.,109

102 On the list of Hidden Lands popular in the Northern Treasure tradition see Gelle, Gter ma a hanyatlás koráról, 247.

103 Sbas yul spyi’i them byang, ed. Dondrup, 2: sbas pa’i yul du 'gro ba la chos skyong pa’i rgyal po gcig dgos tel

104 Sbas yul spyi’i them byang, ed. Dondrup, 16: rgyal po med pas mgo med kyi yan lag 'dra/ It actually refers to the situation of Tibet in the text, but I found it adequate to quote it here, as it reflects the Tibetan view in general as well.

105 Dam tshig. Series of vows or precepts.

106 Gsas is used for Bon deities in general like lha for Buddhists.

107 Sbas pad ma tshal gyi lam yig, ed. Dondrup, 21: btsan po glang 'brug stag lo pa gcig/ btsun mo lug sprel bya lo ma gcig/ dge slong mkhas btsun bzang gsum dang ldan pa gcig dgos/sngags pa dam tshig dang ldan pa gcig/ bon po bsas ma nyams pa gcig/ skyes pa lus stobs dang ldan pa bcu gsum dgos/ de mams thugs mthun par byas la/ rgyal srid chos dang mthun par skyongs/

108 Yol mo gangs ra'i gnad byang, ed. Dondrup, 31: rgyal po byang chub kyi sems dang ldan pa dgos/ bstun pa gtsang spyod dang ldan pa dgos/ bon po bas ma nyams pa gcig dgos/sngags pa byin rlabs dang ldan pa shin tu ga che'o/

109 Yol mo'i snying byang, ed. Dondrup, 42: yul de 'dzin pa la btsad po glang gi lo pa gcig dgos te/ byang gi phyogs nas 'byung/ btsun mo bya lo ma gcig dgos te nub nas 'byung/ mkhan po sde snod 'dzin pa gcig dgos te byang shar nas 'byung/ bon po bsas ma nyams pa gcig dgos te nub byang gi mtshams nas 'byung/ blon po bkod la mkhas pa gcig dgos te nye ba'i 'khor bas 'byung ngo/ 
As mentioned earlier, our sources list several signs of the arrival of the End Times, such as foreign invasion, the lack of central power in Tibet, chaos and civil war, and the three kings of the Gung thang Kingdom being killed by knife. Still, there is no mention of the Gung thang royal line in the prophecies describing the ideal society to be established when arriving in the Hidden Land. The texts only describe the king in general, someone who protects the Dharma and is a lawful, righteous, compassionate person who ensures that everything functions according to the law. In my opinion, this idea is more likely to derive from the rNying ma sentiment about the Golden Age of the eighth century, when the Bodhisattva King Khri srong lde btsan ruled Tibet and Padmasambhava was his teacher, as well as the image in early Buddhist texts of the Cakravartin, the wheel-turning monarch who rules according to the Dharma, ensuring peace and protection for his people.

\subsection{Creating a Paradise on Earth}

In the prophecies revealed to Rig 'dzin rGod ldem, Hidden Lands are described as paradise-like regions where people do not age, life is pleasant, and resources are inexhaustible. However, in order to transform them into auspicious places for Buddhist practice, various rites have to be conducted, and stūpas, temples, retreat places need to be built. The prophecies also stress the importance of local mountain deities and their worship by the new settlers. ${ }^{110}$

The Sbas padma tshal gyi lam yig ("Guidebook to the Lotus Grove”) says:

On the three plains, there is a grove with lotus flowers, a water mill made of precious stones, all kinds of grains grow. As there are various kinds of plants, there are all kinds of herbivores; and because there is nutritious grass, there are all kinds of four-legged animals. If the killing of wild animals is prohibited, the king [will enjoy] long life. Recite sūtras, [and perform] sādhanas of Amitāyus and Ușnīṣavijayā. ${ }^{111}$ Build four stūpas in the four directions of the path and erect a glorious rice-heap stūpa in the centre; that is the way to make a land fortunate. ${ }^{112}$ In later times on the upper part seven thousand yak hair tents will be set up. ${ }^{113}$ In the lower part seven thousand cities will arise. The teaching of the secret mantra will emerge like a rising sun. There is summer and winter [similar to those experienced in] the city of Li. Protect particularly the Dharma treasures and cattle, horse, sheep in the upper part of the land. On the lower part six grains grow, in the centre the imperial law rules. At the three road-gates market places will be established. Furthermore, because it is a fortunate land, people have the treasure of good health, long life and great wealth. Having the five kinds of precious things is the symbol

110 In the Tibetan cultural realm, from early times, the mountain cult related to the territorial divisions of clan society. The mountain deity was the personal protector of the head of the clan, and when a new territory was captured, its mountain deity had to be propitiated and served. Karmay, "The Tibetan Cult of Mountain Deities and Its Political Significance," 63.

111 Buddhas of long life.

112 By building these stūpas, the holy place will be consecrated.

113 Seven thousand nomadic families will settle here. 
of collected prophetic treasures. If a beast of prey appears in that land, give offering to gLe $\mathrm{ru},{ }^{114}$ if a yeti appears, give offering to rDo rje Legs pa, if large and small birds appear, give offering to Cha ti's snow mountain. If you do accordingly, these seven thousand cities will go to the realm of bliss. ${ }^{115}$

\section{And at the end of the same text Padmasambhava says:}

Because sentient beings in general are guided by the five degenerations, ${ }^{116}$ may the door of ' $\mathrm{Og}$ min, ${ }^{117}$ mNgon dga, ${ }^{118}$ dPal ldan, ${ }^{119}$ bDe chen ${ }^{120}$ and Las rab ${ }^{121}$ one above the other, the fivepeaked Khechara, ${ }^{122}$ the Potala ${ }^{123}$ and lCang lo can, ${ }^{124}$ all the law-abiding hidden lands and similar lands, valleys and mountain ranges, rocky places and cave doors open when people arrive there, and may they all attain the supreme and common siddhi ${ }^{125}$ without exception! May all beings reach the place of liberation! May they realise the pure land of the three bodies! ${ }^{126}$

$114 \mathrm{dGe}$ bsnyen gLe ru, one of the mountain deities of Yolmo.

115 Tib. bDe ba can, Skt. Sukhāvatī, Amitābha's pure land. Sbas pad ma tshal gyi lam yig, ed. Dondrup, 21-22: thang gsum la me tog padma'i tshal yod/ rdo'i nor bu'i chu thags yod/ 'bru'i rigs kun smin/ sngo kun dang ldan pas ri dwags kun 'du/ rtswa kun bcud dang ldan pas dud 'gro kun 'tsho/ $r$ rgya byas na rgyal po sku tshe ring/ mdo sgrub dang tshe dpag med gtsug gtor gsung sgrogs/ lam phyogs bzhir mchod rten bzhi rtsigs/ dbus su dpal ldan 'bras spungs mchod rten rtsigs/ de ni yul bkra shis pa'i thabs yin no/ dus phyis phu de la sbra khyim bdun stong chags/ mdo la grong khyer bdun stong chags so/gsang sngags kyi bstan pa nyi ma shar ba 'dra ba gcig yong/li yul dang dbyar dgun byed/ khyad par chos gter dang/ phu ru gnag rta lug gsum skyongs/ mdo ru 'bru drug smin/ bar du rgyal khrims chags/ lam sgo gsum la tshong 'dus 'byung/lar bkra shis pa'i yul yin pas nad nyung/ tshe ring longs spyod gter dang ldan par 'gyur ro/ rin chen sna lnga yod pas gter lung 'dus par brda/ yul der gcan gzan byung na/gle ru mchod/ mi rgod byung na rdor legs mchod/ bya byi byung na cha ti'i gangs mchod/ de ltar byas pas grong khyer bdun stong bde ba can du 'gro/

116 Tib. snyigs ma lnga (Skt. pañcakașāya): the fivefold degeneration: 1. āyuhkașāya (Tib. tshe’i snyigs ma, "degeneration of life"): decline of sustaining life-force, shortening life-span. 2. drșțikașāya (Tib. lta ba'i snyigs ma, "degeneration of views"): decline in the virtue of renunciants, wrong views. 3. kleśakașāya (Tib. nyon mongs kyi snyigs ma, "degeneration of afflictions"): disturbing emotions, decline of virtue among people. 4. sattvakașāya (Tib. sems can gyi snyigs ma, "degeneration of beings"): decline of body to inferior shape and size. 5. kalpakașāya (Tib. bskal pa’i or dus kyi snyigs ma, "degeneration of the era") decline in enjoyments, periods of conflicts. It is quite curious, that only one third of the Tibetan texts writing about kalpakașāya use bskal pa snyigs ma according to the BDRC database, and except works included in the Canon, they are all written after the fourteenth century CE. The other two third of the texts using dus kyi snyigs ma range from the eleventh century or earlier to the present times.

117 Skt. Akanișțha realm.

118 Skt. Abhirati. Akṣobhya's pure land.

119 Skt. Śrīmat. Ratnasambhava's pure land.

120 Skt. Sukhāvatī or Mahāsukha. Amitābha’s pure land.

121 Skt. Karmaprasiddhi. Amoghasiddhi's pure land.

122 Tib. mKha' spyod. The pure land of Vajra Vārāhī.

123 Tib. ri Po ta la. The pure land of Avalokiteśvara.

124 The pure land of Vajradhara (T. rDo rje 'chang), Vajrapāṇi, Kuvera, Vaiśravaṇa.

125 Mastery over physical forces, "attainments". The common siddhis are the power over lifespan, being able to fly and become invisible, do fast walking, being invincible, moving through solid 
The closing words of the Guide to the Hidden Lotus Grove quoted here list the Hidden Lands and remote places of yogic practice together with various buddha-fields or pure lands, places of unworldly purity that represent the journey of bodhisattvas to an enlightened state. It somehow reinforces the idea that Hidden Lands and sacred places can be experienced by their inhabitants at several levels. They are not only ideal places for practice, but on a higher spiritual plane they also represent an enlightened vision that can be attained gradually or non-gradually in this lifetime.

\section{Following the Prophecy}

During the last centuries the followers of the rNying ma School were often criticised by the other schools (gSar ma) for practicing old Tantras and magic. They were often persecuted because of their practices, particularly during the seventeenth and eighteenth centuries by the newly converted Mongolian tribes, such as the Qoshot Mongols who were helping the 5th Dalai Lama to unify Tibet (1641), and the Dzungar Mongols ${ }^{127}$ who raided Tibet in 1717. Among other rNying ma monasteries, the Dzungars destroyed rDo rje brag, ${ }^{128}$ the centre of the Northern Treasure tradition, and killed its abbot Rig 'dzin Padma 'Phrin las (1641-1717). It is known from biographies of Tibetan lamas that during these centuries the treasure texts concerning Hidden Lands unearthed by Rig 'dzin rGod ldem gained great popularity. Yang 'dul temples were whitewashed and renovated by treasure masters and yogis and became starting points for trips to the southern borderlands. During their travels, these yogis often stopped for retreats in power places, conducted magic rites to stop foreign armies invading Tibet ( $\mathrm{dmag}$ zlog, hor $z \log ),{ }^{129}$ and occasionally even settled down in one of the Hidden Lands.

One of these masters was gTer dbon Nyi ma seng ge (1687-1738), whose biography, the Nges shes 'dren pa'i shing rta (“Chariot of Certainty”), was recorded by his

objects like walls, power over the beings in the underworld (nāga, mahoraga, sa bdag, etc.), and clairvoyance. The only supreme siddhi is buddhahood itself.

126 Sbas pad ma tshal gyi lam yig, ed. Dondrup, 22: snyigs ma lnga bdo'i sems can 'dren pa'i phyir/ 'og min mngon dga' dpal ldan bde chen dang/ las rab brtsegs pa mkha' spyod rtse lnga dang/ po ta la dang lcang lo can rnams dang/tshul mthun sbas pa'i yul dang yul 'dra dang/ rong dang ri ra rdza jom thams cad kyi/ sgo phye 'gro ba mang po der bslebs nas/ mchog thun dngos grub ma lus myur thob shog/ 'gro kun thar ba'i gling du bgrod par shog/ sku gsum zhing khams dag la spyod par shog/

127 The Dzungar identity was created by different Oirat tribes, who founded the last great nomadic empire in East Turkestan. As newly converted dGe lugs pas, they persecuted both rNying ma and Bon followers. See Karmay, “A Recently Discovered rnam thar of Lha Bla ma Ye shes 'od,” 320.

128 One of the six main rNying ma monasteries in Tibet. It was rebuilt after the Dzungar invasion, then destroyed again by the Chinese army in the 1960s. Its renewed reconstruction was begun in 2000 .

129 See Gentry, "Representations of Efficacy.” 
son 'Phrin las bdud 'joms, the 5th Yol mo ba chen po. According to this account Nyi ma seng ge was born in Mang yul, and not only possessed, but also closely followed Rig 'dzin rGod ldem's prophetic texts discussed above. ${ }^{130}$ He was the fifth descendent of bsTan gnyis gling pa, the steward of the Byams sprin Temple in Mang yul, which housed many treasure teachings and as a yang 'dul temple was built to pin down the right sole of the demoness' foot. ${ }^{131}$ When the Dzungar army reached the district, Nyi ma seng ge decided to go to charnel grounds located in sacred places in order to perform magic practices aimed against the Dzungars. During his travels on the bank of the Nyi ma khud lake ${ }^{132}$ in Nepal he saw a miraculous omen and set off to the sacred place of Skye ba lung. He gave donations for the building of meditation huts and founded retreat centres, and on visiting the Kathmandu valley renovated the two great stūpas, the Bya rung kha shor and the Swayambhu (Tib. 'Phags pa shing kun). After his return to Mang yul, plague broke out in the Kathmandu valley, and King Jagajjaya Malla (1722-1734) ${ }^{133}$ invited him back to perform Tantric rituals in order to stop the epidemic. ${ }^{134}$ After his success, the king granted him land in Yolmo, and this gift was documented on copperplate. ${ }^{135}$ During an interview I conducted on clan history in Tarkeghyang village in Yolmo, my informant told me that his clan ancestor was a certain Myes myes Karma dbang phyug of Tongsi village ${ }^{136}$ in the sKyid rong area, who accompanied Nyi ma seng ge with his people as his sponsors when he moved to Yolmo, and there was a group from another sKyid rong village travelling with them, who formed the Ayogpa clan, which had already died out in Tarkeghyang. According to his biography, when Nyi ma seng ge arrived with his people in Yolmo, he immediately started to transform the land according to Rig 'dzin rGod ldem's prophecy:

130 GSS,

131 Sørensen and Hazod, Thundering Falcon, 399.

132 According to the biography of Padmasambhava included in the Zab pa skor bdun ( $O$ rgyan thar dpag bsan ljong shing) revealed by gTer ston $O$ rgyan mchog gyur gling pa (1829-1870), Padmasambhava subjugated the mountain gods (gnod sbyin) and the cannibal spirits (srin po) at that lake. For an English translation, see Dowman, The Legend of the Great Stupa, 70.

133 The ruler of independent Kathmandu during the three kingdom (Pātan, Bhaktapur, Kathmandu) period (1482-1769).

134 Si tu pan chen (1699-1774) writes about a delegation of Karma pa lamas being invited by the same king, Jagajjaya Malla, to his Kathmandu court in 1723. When he asked the lamas to perform some kind of miracle to stop the epidemic, they responded that they did not have the ability to perform miracles but would do everything to stop the epidemic. See Verhagen, "Si tu pan chen," 328-329.

135 Two copies of these copperplate landgrants were translated and published by Clarke, "A Helambu History," 15-16.

136 In Yolmo his descendants belong to the Tongso clan. 
He was thinking to build a temple. When he looked at the geomantic signs, the precious heart of the place was [a mountain] planted there like a refuge tree, ${ }^{137}$ and accordingly, as it was prophesied in the guidebook and the prophetic manual ${ }^{138}$ he built [the temple] there on the top of g.Yang ri with great hardships. As it is written in the prophetic manual: 'surrounded by valleys from right and left, in the middle of the offering place there is a marvellous circular mountain top. ${ }^{139}$ On the top of that mountain, Ârya Avalokiteśvara's magnificent temple should be built.' There was stone and wood in this place, so he did the cleansing ritual of rDo rje rNam 'joms. ${ }^{140}$ They made sure that the direction [of the building] was not wrong. The [building's] measurement was right. There were three [storeys]: upper, middle and lower. In every direction sixteen arms length, and alternately eight, and four. In the manner of the terraces of Mount Meru there were three levels. It was essential [to make it] firm and stable. ${ }^{141}$

The temple was built in the same style as the Mang yul Byams sprin Temple, the place Nyi ma seng ge came from. The main structure and the floors were made of Nepalese red pinewood, the three roofs of the upper, middle and lower floor were covered with slates, and sculptors were invited from gNya' nang to make the statues out of a mix of herbs and clay. The three storeys of the temple housed three shrines, and the inner arrangements and statues also closely followed the description of the prophecy. ${ }^{142}$ On the ground floor, there was a Nirmānakāya ${ }^{143}$ shrine with the statue of an eleven-headed and thousand-armed Avalokiteśvara (sPyan ras gzigs). On the middle floor, there was a Sambhogakāya shrine with a three-headed red

137 Rin chen mchod sdong can be translated as a stūpa, an offering lamp or a refuge tree (tshogs shing). The emphasis here is on the shape, which is very similar in all three cases.

138 See Yol mo gangs kyi ra ba'i lung byang snying gi tikka in the bibliography.

139 In the original prophecy, this is followed by two more sentences (Yol mo gangs kyi ra ba'i lung byang snying gi țikka, ed. Dondrup, 37: de’i steng nas phyogs mtshams su bltas pa dang/ mtha' skor na thang gsum yod/). These are omitted from Nyi ma seng ge's biography, probably because of their lack of relevance to temple building. Otherwise the prophecy is quoted verbatim.

140 Skt. Vajravidārana. It is a consecration ritual during which all construction materials, wood and stones are sprinkled with holy water.

141 GSS 17a-b: de nas gtsug lag khang zhig bzhengs par dgongs te sa dpyad gzigs pas/ gnas kyi snying po rin chen mchod sdong btsugs pa 'dra ba dbyangs ri'i rtser gnas yig lung byang ltar bzhengs pa la dka' brtsegs shin tu che ba 'dug pa ni/ lung byang las/ (quoting Yol mo gangs kyi ra ba'i lung byang snying gi țikka, ed. Dondrup, 37) g.yas g.yon rong gi mchod pa’i dbus na ri rtse zlum brjid bzang ba zhig yod/ ri de'i rtse la 'phags pa thugs rje chen po'i khyad par rmad du byung ba'i lha khang rtsig dgos/de'i sa rdo shing mams kyang rdo rje rnam 'joms kyi khrus nas bton/phyogs ma nor bar byas te/ rgya che chung nges pa med/ rab 'bring tha ma gsum ste/ phyogs re la 'dom bcu drug pa'am/ brgyad pa'am/ bzhi ba'am/ ri rab bang rim gyi tshul du rim pa gsum yod pa gcig bzhengs/ de sra zhing brtan pa gal che/

142 Yol mo gangs kyi ra ba’i lung byang snying gi țikka, ed. Dondrup, 37-38.

143 The Trikāya (Tib. sku gsum) or "Three Bodies" doctrine is a teaching on the nature of reality and the nature of buddhahood. Nirmānakāya is the body that manifests in time and space, the Buddha's manifestation in the physical world. Sambhogakāya is the enjoyment body of the Buddha that manifests in clear light, either in a vision or in deep meditation. Dharmakāya is the body of Truth that has no limits or boundaries, it is the Buddha-nature's emptiness of conceptualizable essence. 
Mahākārunika (Thugs rje chen po). The top floor housed a Dharmakāya shrine, where Amitābha's ('Od dpag med) statue was held as the main image.

The prophecy also gave instructions for establishing settlements:

At the foot of this mountain on the east, there is a plain. Establish a place here for ordained monks and upāsaka (lay people), for all the Dharma practitioners. To the southwest there is a plain. Establish a place there for householders and common people. To the north there is a plain. Establish a place there for Tantric practitioners. ${ }^{144}$

In 1723 Nyi ma seng ge founded Tarkeghyang village at the foot of the mountain, and a retreat place named Grub pa sdong on the east. The temple built by him on the g.Yang ri mountain was destroyed after a while, ${ }^{145}$ but both the village and the retreat centre are still there, and the wish to fulfil Padmasambhava's prophecy never diminished in Yolmo. Some say that he was the initiator of the custom of annual pilgrimage from the village to the mountain top as well, held on the full-moon day of the second Tibetan month. In the twentieth century Bya bral Rin po che (Sangs rgyas rdo rje, 1913-2015), established further centres of practice, and even opened a Hidden Valley called Bemthang in the north.

\section{Conclusion}

The cult of Hidden Lands in the Northern Treasure tradition is a very complex topic, and my aim here was only to explore its roots in Indian Buddhist thought and cosmology, and to show how teachings regarding the Age of Decline were transferred through time and between cultures, how the rNying ma tradition utilised Buddhist texts from India and Central Asia translated into Tibetan for formulating its prophecies on Hidden Lands, and how through treasure transmission these texts had an impact on the activities of an eighteenth-century Tibetan lama settling in Yolmo. The purpose of a prophecy is primarily of a moral and salvific nature. As we have seen, the prophetic teachings regarding the Hidden Land of Yolmo provide information about the present situation in Tibet (chaos and moral decline), warn about coming disasters (foreign invasion, natural catastrophes), encourage the right course of action (escape and practice the Dharma in a new and safe place, live a virtuous life), and give a glimpse of possible future realisations (reaching the Hidden Land and live happily, be reborn in a pure land, meet Padmasambhava in the next

144 Yol mo gangs kyi ra ba’i lung byang snying gi țikka, ed. Dondrup, 38-39: ri de’i shar phyogs kyi ri 'dabs la thang gcig yod/ dge slong dang dge bsnyen rgyu'i chos spyod pa thams cad kyi gnas gdab/ de'i lho nub phyogs na thang gcig yod/ der skya bo dang dmangs kyi gling gdab/ de'i byang phyogs na thang gcig yod/ gsang sngags bsgrub pa rnams kyi gling gdab/

145 For details of the temple construction see Gelle, “Jolmó maṇdala - Horváth Z. Zoltán emlékére,” 142. 
life). They allow men to exercise free choice, but by describing possible futures, they strongly encourage them to follow the track illuminated by the prophecy. They give hope and comfort to all those whose lives are threatened, or who wish to have better conditions for spiritual practice. Their modernity lies in their relevance, and their relevance lies in their constant reinterpretation.

Instead of a longer summary, I included all the important elements of my argument in a table for further consideration and discussion.

Tab. 1

\begin{tabular}{|c|c|c|c|}
\hline & Indian prophecies & Jangter prophecies & Nyima Sengge \\
\hline 1. External causes & 3 kings will attack India & $\begin{array}{l}\text { When the Mongols and } \\
\text { Turks attack Tibet => } \\
\text { It is time to escape }\end{array}$ & Moves to a Hidden Land \\
\hline 2. Internal causes & $\begin{array}{l}\text { The five kașāyas will } \\
\text { permeate everything, } \\
\text { society will disintegrate }\end{array}$ & $\begin{array}{l}\text { When the five kașāyas } \\
\text { permeate everything, } \\
\text { and society disintegrates } \\
\Rightarrow>\text { Live a virtuous life in } \\
\text { a Hidden Land }\end{array}$ & $\begin{array}{l}\text { Establishes a temple vil- } \\
\text { lage for his people who } \\
\text { accompanied him to Ne- } \\
\text { pal }\end{array}$ \\
\hline $\begin{array}{l}\text { 3. State of the } \\
\text { Teaching }\end{array}$ & $\begin{array}{l}\text { Stūpas, books will be } \\
\text { destroyed, and disciples } \\
\text { killed in India }\end{array}$ & $\begin{array}{l}\text { When stūpas, books, } \\
\text { temples are destroyed in } \\
\text { Tibet, and practitioners } \\
\text { killed => } \\
\text { Renovate temples and } \\
\text { stūpas to delay the end } \\
\text { of times in Tibet. } \\
\text { In case you have fled al- } \\
\text { ready, transform the new } \\
\text { land and build places for } \\
\text { practitioners }\end{array}$ & $\begin{array}{l}\text { Builds stūpas, temples, } \\
\text { retreat centers; starts the } \\
\text { tradition of annual pil- } \\
\text { grimage }\end{array}$ \\
\hline $\begin{array}{l}\text { 4. Righteous rule } \\
\text { and royal lineage }\end{array}$ & $\begin{array}{l}\text { Last representatives of } \\
\text { the Dharma and even the } \\
\text { last king ruling according } \\
\text { to the Dharma dies }\end{array}$ & $\begin{array}{l}\text { When the imperial era is } \\
\text { over, and there is no king, } \\
\text { only chaos and disinte- } \\
\text { gration => } \\
\text { Create an ideal society in } \\
\text { a new place }\end{array}$ & $\begin{array}{l}\text { Lives a virtuous life as } \\
\text { head of a community of } \\
\text { practitioners }\end{array}$ \\
\hline 5. End of the era & Darkness, Māra laughing & $\begin{array}{l}\text { When there is darkness } \\
\text { in Tibet and Māra is } \\
\text { laughing => } \\
\text { Start a new life in a new } \\
\text { place under Padmasamb- } \\
\text { hava's protection } \\
\text { In the next life you will be } \\
\text { reborn in a Pure Land }\end{array}$ & $\begin{array}{l}\text { People survive the bad } \\
\text { times in a Hidden Land in } \\
\text { safety under Padma- } \\
\text { sambhava's protection }\end{array}$ \\
\hline
\end{tabular}




\section{Bibliography}

\section{List of Abbreviations}

BDRC Buddhist Digital Resource Center

D Derge (sDe dge) Edition of the Tibetan Canon

GSS Gu ru Sūrya Sengge'i rnam thar mdor bsdus nges shes 'dren pa'i shing rta, (Manuscript photographed by the author in Nepal) fs. 36

IOL India Office Library

LTWA Library of Tibetan Works and Archives

PTS Pāli Text Society

T Taishō Tripitaka

\section{Primary Sources}

Byang gter lugs kyi rnam thar dang ma 'ongs lung bstan ("Biographies and Future Prophecies of the Northern Treasure Tradition”). Edited by Sherab Gyaltsen and Lama Dawa. Gangtok: Palace Monastery, 1983. Reproduced from manuscripts from the library of Lama Sengge of Yolmo. BDRC: W27866; LTWA No. Ka.3:77-2221, fs. 598.

Bu ston Rin chen grub (1290-1364), Chos 'byung gsung rab rin po che'i mdzod. Beijing, 1991.

Cakkavatti-sīhanāda-sutta. In The Dïghanikāya, vol. 3, edited by Thomas William Rhys Davids and Joseph Estlin Carpenter, 58-79. Lancaster: Pali Text Society, 1911; recent reprint with corrections 2006.

The Connected Discourses of the Buddha. A Translation of the Samyutta Nikāya. Translated by Bhikku Bodhi. Boston: Wisdom Publications, 2000.

The Numerical Discourses of the Buddha. A Translation of the Ariguttara Nikāya. Translated by Bhikku Bodhi. Boston: Wisdom Publications, 2012.

Gu ru Sūrya Sengge'i rnam thar mdor bsdus nges shes 'dren pa'i shing rta (Manuscript photographed by the author in Nepal) fs. 36.

mChod rten chen po bya rung kha shor gyi lo rgyus thos pa grol ba. In Bya rung kha shor gyi lo rgyus, 9-54. Gangtok: Sherab Gyaltsen Palace Monastery, 1983.

Sbas yul spyi'i them byang (“General Description of Hidden Lands"). In Sbas yul spyi dang bye brag yol mo gangs ra'i gnas yig, edited by Nyima Dondrup, 1-19. Kathmandu: Khenpo Nyima Dondrup, 2003.

Sbas pad ma tshal gyi lam yig / gter ston sprul pa lha btsun gyi phyag ris las bshus pa ("Guide to the Lotus Grove, Copied by Lhatsun, the Treasure-Revealer Incarnation by his Own Hands"). In Sbas yul spyi dang bye brag yol mo gangs ra'i gnas yig, edited by Nyima Dondrup, 20-22. Kathmandu: Khenpo Nyima Dondrup, 2003.

Yol mo gangs kyi ra ba'i gnad yig ("Essential Instructions on the Yolmo Snow Enclosure"). In Sbas yul spyi dang bye brag yol mo gangs ra'i gnas yig, edited by Nyima Dondrup, 23-27. Kathmandu: Khenpo Nyima Dondrup, 2003.

Yol mo'i snying byang ("Quintessential Inventory of Yolmo"). In Sbas yul spyi dang bye brag yol mo gangs ra'i gnas yig, edited by Nyima Dondrup, 28. Kathmandu: Khenpo Nyima Dondrup, 2003.

Yol mo gangs ra'i gnad byang ("Essential Guide to the Yolmo Snow-Enclosure"). In Sbas yul spyi dang bye brag yol mo gangs ra'i gnas yig, edited by Nyima Dondrup, 29-32. Kathmandu: Khenpo Nyima Dondrup, 2003. 
Yol mo gangs kyi ra ba'i lung byang snying gi țikka ("Heart-Essence of the Prophetic Certificate of Yolmo Snow-Enclosure”). In Sbas yul spyi dang bye brag yol mo gangs ra'i gnas yig, edited by Nyima Dondrup, 33-43. Kathmandu: Khenpo Nyima Dondrup, 2003.

Ma' 'ongs lung bstan sbas yul gyi them byang. In 'Bras mo ljongs kyi gnas yig gi dkar chag, edited by Buddhist Digital Resource Center, W1KG818: 101-115. Gangtok: Namgyal Institute of Tibetology/Dharamsala: Amnye Machen Institute, 2008.

Thus Have I Heard. The Long Discourses of the Buddha: Digghanikāya. Translated by Maurice Walshe. London: Wisdom Publications, 1987.

\section{Secondary Literature}

Apple, James B. "Eschatology and World Order in Buddhist Formations." Religious Studies and Theology 29, no. 1 (2010): 109-122.

Bernbaum, Edwin. The Way to Shambhala. A Search for the Mythical Kingdom Beyond the Himalayas. Los Angeles: Jeremy P. Archer, 1980.

Boord, Martin. "Pilgrims Guide to the Hidden Land of Sikkim Proclaimed as a Treasure by Rig 'dzin Rgod kyi Idem 'phru can." Bulletin of Tibetology 39/1 (2003): 31-53.

Brauen-Dolma, Martin. Milleniarism in Tibetan religion. In Soundings in Tibetan Civilization, edited by Barbara Nimri Aziz and Matthew Kapstein, 245-256. New Delhi: Manohar, 1985.

Brough, John. "Legends of Khotan and Nepal." Bulletin of the School of Oriental and African Studies 12/2 (1948): 333-339.

Buswell, Robert E. and Padmanabh S. Jaini. "The Development of Abhidharma Philosophy." In Encyclopedia of Indian Philosophies, Vol. VII. Abhidharma Buddhism till 150 A.D., edited by Karl H. Potter, Robert E. Buswell, Padmanabh S. Jaini, Noble Ross Reat, 73-119. Delhi: Motilal Banasidass, 1996.

Childs, Geoff. "Refuge and Revitalization: Hidden Himalayan Sanctuaries (sbas-yul) and the Preservation of Tibet's Imperial Lineage." Acta Orientalia 60 (1999): 126-158.

Clarke, Graham. "A Helambu History.” Journal of the Nepal Research Centre 4 (1980): 1-38.

Cuevas, Bryan J. The Hidden History of the Tibetan Book of the Dead. Oxford: Oxford University Press, 2003.

Diemberger, Hildegard. "Gangla Tshechu, Beyul Khembalung: Pilgrimage to Hidden Valleys, Sacred Mountains and Springs of Life Water in Southern Tibet and Eastern Nepal." In Anthropology of Tibet and the Himalaya, edited by Charles Ramble and Martin Brauen, 60-72. Zürich: Museum für Völkerkunde, 1993.

Diemberger, Hildegard. "Beyul Khenbalung, the Hidden Valley of the Artemisia." In Mandala and Landscape, edited by Alexander W. Macdonald, 287-334. New Delhi: D. K. Printworld, 1997.

Doctor, Andreas. Tibetan Treasure Literature. Revelation, Tradition and Accomplishment in Visionary Buddhism. Ithaca: Snow Lion, 2005.

Dowman, Keith. The Legend of the Great Stupa. Berkeley: Dharma Publishing, 2004.

Dudjom, Rinpoche. The Nyingma School of Tibetan Buddhism. Its Fundamentals and History. 2 vols, edited and translated by Gyurme Dorje and Matthew Kapstein. Boston: Wisdom Publications, 1991.

Ehrhard, Franz-Karl. "A 'Hidden Land' in the Nepalese-Tibetan Borderlands." In Mandala and Landscape, edited by Alexander W. Macdonald, 335-364. New Delhi: D. K. Printworld, 1997.

Ehrhard, Franz-Karl. "The Role of 'Treasure-Discoverers' and Their Writings in the Search for Himalayan Sacred Lands." In Sacred Places and Powerful Places in Tibetan Culture, edited by Tony Huber, 227-239. Dharamsala: LTWA, 1999. 
Gelle, Zsóka. Gter ma a hanyatlás koráról. Szerzőség és hitelesség kérdése egy tibeti szöveg kapcsán. In Kéklö hegyek alatt lótuszok tava - Tanulmányok Bethlenfalvy Géza tiszteletére, edited by Beáta Kakas and Zsolt Szilágyi, 241-253. Budapest: L'Harmattan, 2015.

Gelle, Zsóka. “Jolmó maṇdala - Horváth Z. Zoltán emlékére.” Keréknyomok 9 (2015): 133-144.

Gentry, James. "Representations of Efficacy: The Ritual Expulsion of Mongol Armies in the Consolidation and Expansion of the Tsang (Gtsang) dynasty." In Tibetan Ritual, edited by José Ignazio Cabezón, 131-163. New York: Oxford University Press, 2010.

Goodman, Steven D. Rig 'dzin 'Jigs med gling pa and the kLong chen sNying thig. In Tibetan Buddhism. Reason and Revelation, Steven D. Goodman, Ronald M. Davidson, 133-146. Albany: State University of New York Press, 1992.

Gombrich, Richard. How Buddhism Began: The Conditioned Genesis of the Early Teachings. New Delhi: Munshiram Manoharlal Publishers, 1997.

Gyatso, Janet. “The Logic of Legitimation in the Tibetan Tradition.” History of Religions 33/2 (1993): 97-134.

Herweg, Jürgen W. “The Hagiography of Rig 'dzin Rgod kyi Idem 'phru can and Three Historic Questions Emerging from it." MA thesis, University of Washington, 1994.

Huber, Toni. "A Pilgrimage to La-phyi: The Sacred and Historical Geography of a Holy Place in South-Western Tibet." In Mandala and Landscapes, edited by Alexander W. Macdonald, 233286. Delhi: D. K. Printworld, 1997.

Huber, Toni. The Cult of the Pure Crystal Mountain - Popular Pilgrimage and Visionary Landscape in Southeast Tibet. Oxford: Oxford University Press, 1999.

Jamgön, Kongtrül Lodrö Taye. Myriad Worlds: Buddhist Cosmology in Abhidharma, Kālacakra and Dzog-chen. Ithaca: Snow Lion, 1995.

Karmay, Samten. "The Tibetan Cult of Mountain Deities and Its Political Significance." In Reflections of the Mountain. Essays on the History and Social Meaning of the Mountain Cult in Tibet and the Himalaya. eds. Anna-Marie Blondeau and Ernst Steinkellner. Wien: Verlag der Österreichische Akademie der Wissenschaften, 1996.

Karmay, Samten. “A Recently Discovered rnam thar of Lha Bla ma Ye shes 'od." In Tibet After Empire: Culture, Society and Religion between 800-1000, edited by Christoph Cüppers, Robert MMayer, Michael Walter, 229-238. Vol. 4, LIRI Seminar Proceedings Series. Lumbini: Lumbini International Research Institute, 2013.

Lamminger, Navina. "Der sechste Zhva dmar pa Chos kyi dbang phyug (1584-1630) und sein Reisebericht aus den Jahren 1629/1630: Studie, Edition und Übersetzung.” PhD diss, Ludwig-Maximilians Universität München, 2013.

Lamotte, Étienne. History of Indian Buddhism from the Origins to the Śaka Era. Publications de l'Institut Orientaliste de Louvain 36. Translated by Sara Webb-Boin under the supervision of Jean Dantinne. Paris: Peeters Press, 1988.

Mullard, Saul. Opening the Hidden Land. State Formation and the Construction of Sikkimese History. Leiden: Brill, 2011.

Nattier, Jan. Once Upon a Future Time: Studies in a Buddhist Prophecy of Decline. Berkeley: Asian Humanities Press, 1991.

Orofino, Giacomella. "The Tibetan Myth of the Hidden Valley in the Visionary Geography of Nepal." East and West 41 (1991): 239-271.

Regmi, Mahesh C. Land Tenure and Taxation in Nepal. Volume 3: The Jagir, Rakam, and Kipat tenure systems. Berkeley: Institute of International Studies, University of Berkeley, 1965.

Reinhard, Johan. "Khembalung: The Hidden Valley." Kailash 6, no. 1 (1978): 5-35.

Sadakata, Akira. Buddhist Cosmology. Philosophy and Origins. Tokyo: Kōsei Publishing Co., 1997.

Sardar-Afkhami, Hamid. "An Account of Padma-bkod: A Hidden Land in Southeastern Tibet." Kailash 18/3-4 (1996): 1-21. 
Sardar-Afkhami, Hamid. “The Buddha's Secret Gardens: End-Times and Hidden-Lands in Tibetan Imagination." PhD diss, Cambridge/Mass.: Harvard University, 2001.

Shakabpa, Tsepon W.D. Tibet. A Political History. New Haven and London: Yale University Press, 1967.

Sørensen, Per K. The Mirror Illuminating the Royal Geneologies. Wiesbaden: Harrassowitz Verlag, 1994.

Sørensen, Per K. and Hazod, Guntram. Thundering Falcon. An Inquiry into the History and Cult of Khra-brug Tibet's First Buddhist Temple. Wien: Verlag der Österreichischen Akademie der Wissenschaften, 2005.

Stein, Rolf Alfred. Tibetan Civilization. London: Faber \& Faber, 1972.

Tambiah, Stanley J. World Conqueror and World Renouncer. A Study of Buddhism and Polity in Thailand against a Historical Background. Cambridge: Cambridge University Press, 1976.

Thondup, Tulku. "The Terma Tradition of the Nyingmapa School." Tibet Journal 15, no. 4 (1990): 149-158.

Verhagen, Peter. "Si tu paṇ chen: A Tibetan Sanskritist in Nepal." JIATS 7 (2013): 316-339.

Vitali, Roberto. "Sa skya and the mNga' ris skor gsum Legacy: The Case of Rin chen bzang po's flying mask." In Lungta 14: Aspects of Tibetan History, edited by Tashi Tsering and Roberto Vitali, 5-44. Dharamsala: Amnye Machen Institute, 2001. 


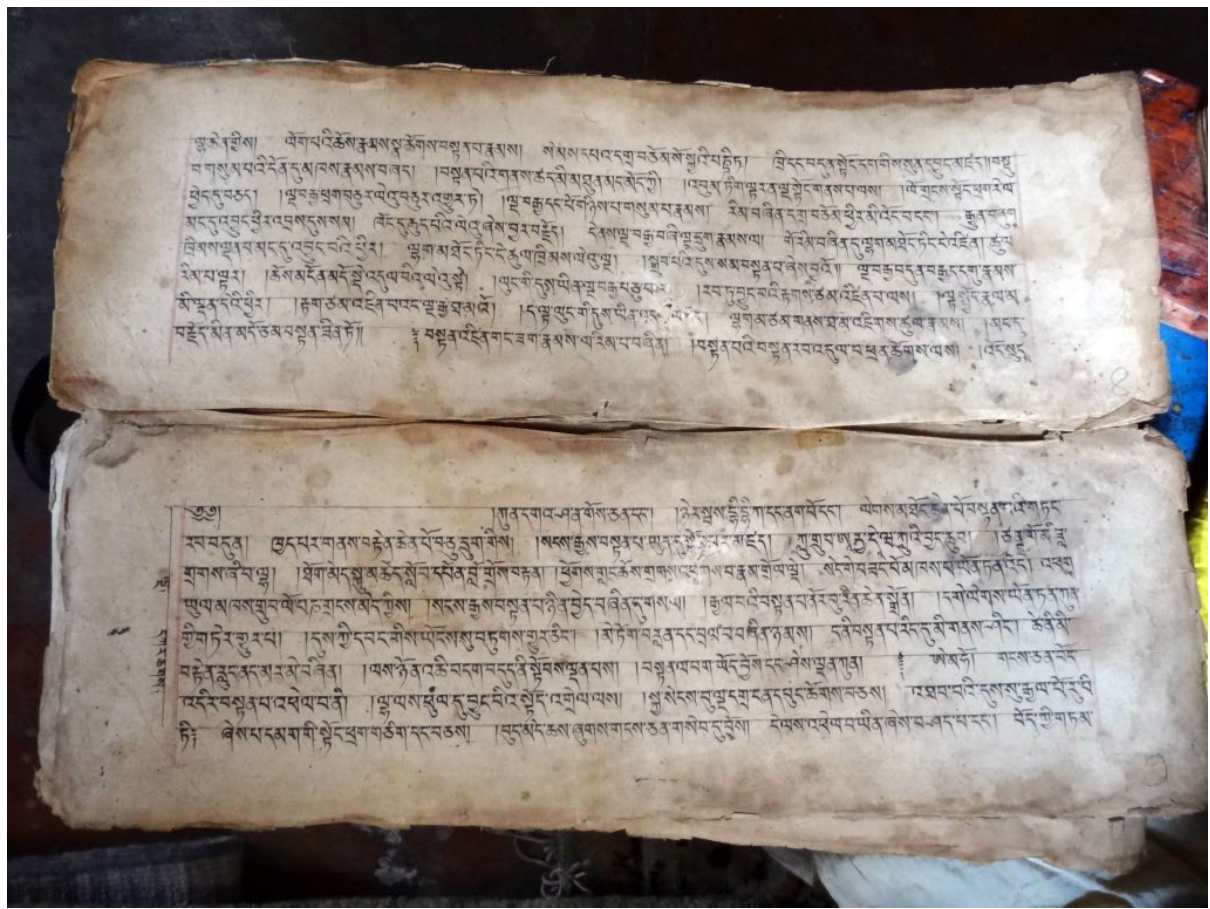

Fig. 2: The Melamchi Karchag mentions the temple built by gTer bon Nyi ma Seng ge, standing on gYang ri peak (C Zsóka Gelle 2012)

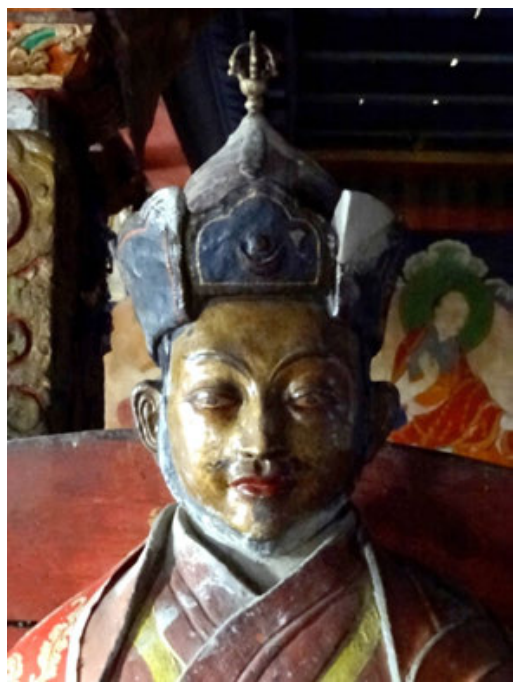

Fig. 3: gTer dbon Nyi ma seng ge's statue on the upper floor of Tarkeghyang Gonpa. In 2015 a big earthquake destroyed this temple (C Zsóka Gelle 2012) 


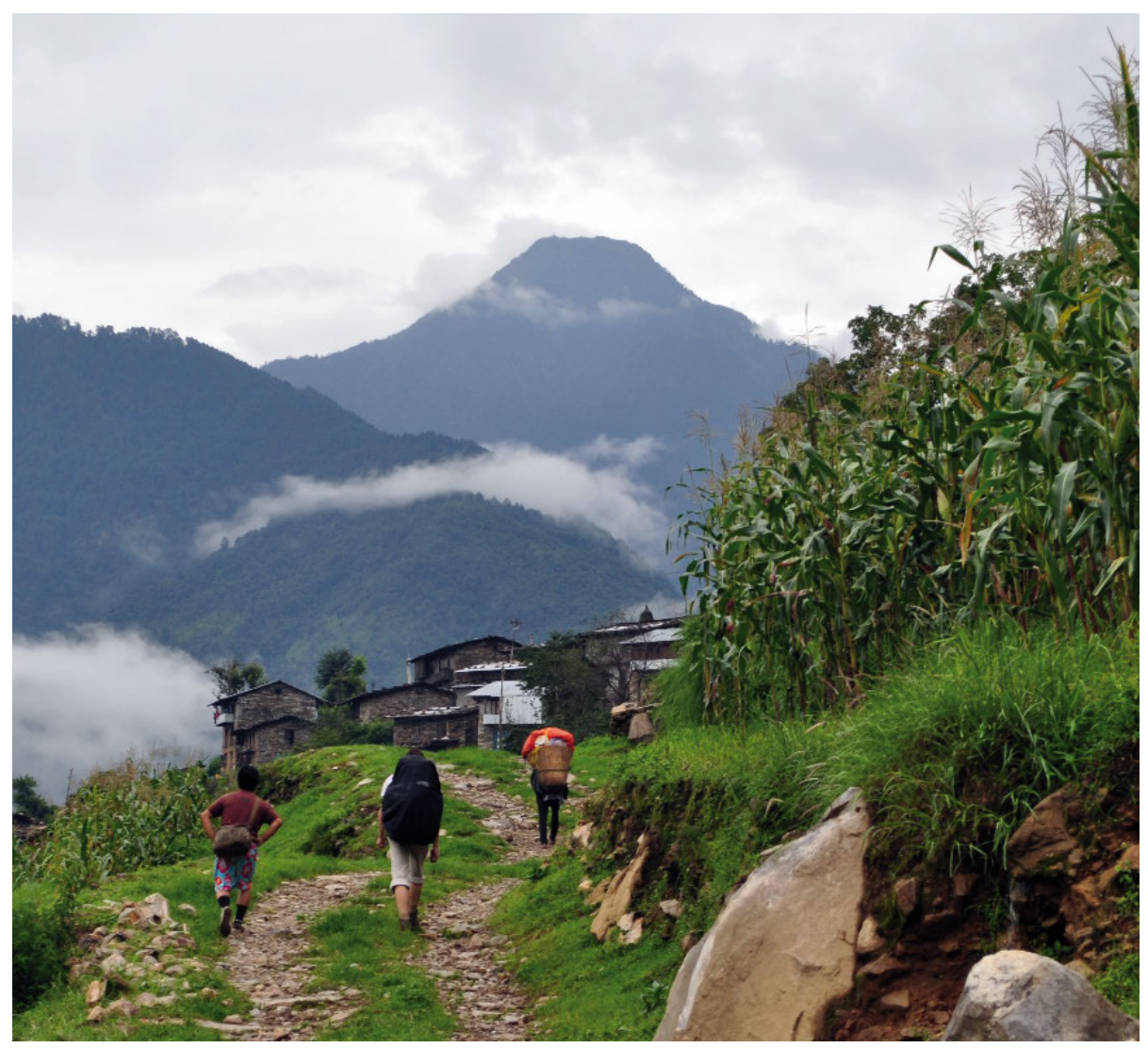

Fig. 4: gYang ri peak (3771 m) from the east (@ Zsóka Gelle 2010) 